\title{
A Cross-National Comparison of Statistics Curricula *
}

\author{
Aslıhan Batur ${ }^{a}$, Zeynep Medine Özmen ${ }^{b}$, Beyda Topanc, Kemal Akoğlu ${ }^{d}$ and Bülent Güven \\ ${ }^{a}$ Artvin Çoruh University, Faculty of Education, Artvin/Turkey (ORCID: 0000-0002-4461-0615) \\ ${ }^{\mathbf{b}}$ Trabzon University, Fatih Faculty of Education, Trabzon/Turkey (ORCID: 0000-0003-0232-9339) \\ ${ }^{\mathbf{c}}$ Ondokuz Mayis University, Faculty of Education, Samsun/Turkey Turkey (ORCID: 0000-0001-6680-2450) \\ ${ }^{\mathbf{d} B o g ̆ a z i c ̧ i ~ U n i v e r s i t y, ~ F a c u l t y ~ o f ~ E d u c a t i o n, ~ I ̇ s t a n b u l / T u r k e y ~(O R C I D: ~ 0000-0002-5688-1316) ~}$ \\ ${ }^{\mathbf{e}}$ Trabzon University, Fatih Faculty of Education, Trabzon/Turkey (ORCID: 0000-0001-8767-6051)
}

Article History: Received: 10 September 2020; Accepted: 2 January 2021; Published online: 4 February 2021

\begin{abstract}
The purpose of this study is to compare Turkey to several other countries such as Singapore, Korea, the United States, and New Zealand according to the field of statistics learning in the curriculum. GAISE (Guidelines for Assessment and Instruction in Statistics Education) framework suggests using the components of statistical process (formulate question, collect data, analyze data, interpret results) and developmental levels of statistical process (Levels A, B, and C) in such comparisons. It is found that in both Korea and Turkey, the number of learning outcomes of statistics, as well as the weight of learning outcomes in the curriculum, have been having a weaker profile than in other countries. The field of statistics learning is mostly condensed around Level A in Turkey. On the other hand, other countries in the study included more Level B and C. Considering the importance of statistics instruction, Turkey's national mathematics curriculum needs improvements in its field of statistical learning. This study suggests designing and developing new standards for teaching statistics that deal with higher developmental levels of statistical process.
\end{abstract}

Keywords: Statistics education, Levels of statistical process, Comparative study

DOI: $10.16949 /$ turkbilmat.793285

Öz: Bu çalışmada Türkiye ile Singapur, Kore, Amerika ve Yeni Zelanda'nın matematik öğretim programlarının istatistik öğrenme alanı açısından karşılaştırılması amaçlanmıştır. Bu karşılaştırmalarda GAISE (İstatistik Eğitiminde Öğretim ve Değerlendirme için İlkeler) raporunda istatistik öğretimine yönelik tavsiye edilen istatistiksel süreç aşamaları (problem durumunu belirleme, veri toplama, veri analizi ve sonuçları yorumlama) ve bu aşamalar için tanımlanan, temelden gelişmişe doğru olarak belirlenen üç seviye (A, B ve C seviyeleri) dikkate alınmıştır. Araştırmanın sonucunda, Kore ve Türkiye'nin hem istatistik kazanım sayısı hem de bu kazanımların öğretim programındaki ağırlığı açısından diğer ülkelere kıyasla daha zayıf bir profile sahip olduğu tespit edilmiştir. Ülkemizdeki kazanımların ağırlıklı olarak temel seviyede (A seviyesi) yoğunlaştığı, diğer ülkelerde ise daha çok B ve C seviyesine odaklanan kazanımların olduğu görülmüştür. İstatistik öğretiminin önemi göz önüne alındığında, ülkemizde matematik öğretim programında istatistik öğrenme alanına ait kazanımların sayısının hem artırılması hem de bu kazanımların daha yüksek seviyelerle ilișkili olarak ele alınması önerilmektedir.

Anahtar Kelimeler: İstatistik eğitimi, İstatistiksel süreç aşamaları, Karşılaştırmalı çalışma

Türkçe sürüm için tıklayınız

\section{Introduction}

In a life surrounded by data, the need to make effective decisions and inferences from data makes it a necessity for individuals to have required knowledge and skills related to statistics and to transfer them to their daily life. As a matter of fact, individuals equipped with such skills in statistics are able to make sense of the data complexity they encounter and to make effective decisions. In the standards of National Council of Teachers of Mathematics [NTCM] (2000), it is pointed out to the importance given to statistical information in keeping up with changing world conditions and it is stated that statistics constitute one of the cornerstones of mathematics education. In addition, the ultimate goal of statistics education, it is stressed that raising individuals as statistically literate and to be able to transfer their statistical knowledge to their lives (Franklin et al., 2007). Today, in parallel with the increasing need to raise students with statistical thinking competence, it is also important to make improvements in statistics teaching at all educational levels (Cooper, 2002). Parallel to this importance, statistics topics are taught more widely in all educational levels from primary school to university in many countries, and recommendations that improve statistics teaching are encountered (Ben-Zvi, \& Garfield, 2008). This orientation to the field of statistics learning has also affected our country and it is seen that with the regulation made by the Ministry of National Education [MoNE] (2005), subjects and learning outcomes related to this field have been included in the mathematics curriculum since 2005. On the other hand, in order to raise

Corresponding Author: Aslihan Batur (iD email: aslihanbatur729@artvin.edu.tr

* A part of this study was presented as an oral presentation at the 1st International Conference on Science, Mathematics, Entrepreneurship and Technology Education.

Citation Information: Batur, A., Özmen, Z. M., Topan, B., Akoğlu, K., \& Güven, B. (2021). A Cross-National Comparison of Statistics Curricula. Turkish Journal of Computer and Mathematics Education, 12(1), 187-201. https://doi.org/10.16949/turkbilmat.793285 
students as statistically literate, it is important that the changes in the mathematics curriculum in our country should reflect the trends towards statistics education worldwide. This situation undoubtedly causes countries to differentiate in terms of statistical literacy, statistical thinking, and statistical reasoning competencies, which are defined as important outcomes of statistics education and the weight they give to the field of statistics learning in the mathematics curriculum. Accordingly, it is necessary to examine the field of statistics learning in mathematics curriculum in different countries and to compare this field $n$ our country with the others. In this study, it is aimed to compare Turkey to several other countries such as Singapore, Korea, USA, and New Zealand according to the field of statistics learning in the curriculum. For this aim, learning outcomes in the field of statistics learning have been compared. Learning outcome has been specified as "content" in Singapore and Korea, "standard" in USA. ,and "goal" in New Zealand. In order to prevent these differences from causing confusion, the expression "learning outcome" is used in the present study.

\subsection{Theoretical Framework}

In this study, the theoretical framework included in the GAISE report (Franklin et al., 2007), which draws attention to the principles determined for statistics instructionwas used in comparing mathematics curriculum of countries in terms of the field of statistics learning. In the report, statistical process is taken as a basis for teaching statistics, and instructional practices that bring statistical process components to the forefront are explained. In addition, the framework presented in this report, the aspects related to the statistical process components were discussed at three hierarchical levels (A, B and C). While analysing the mathematics curriculums of the countries included in this study in terms of the field of statistics learning, it was based on statistical process components and the three hierarchical levels related to these components.

\subsubsection{Statistical Process}

Statistics allow individuals to direct their lives and to realize different types of thinking about the quality of their decisions. Based on this importance of statistics, it is a substantial need to teach statistics in schools effectively. In the GAISE report, it is underlined that the effectiveness of the student in the learning environment is a significant variable in increasing the quality of statistics instruction (Franklin et al., 2007). It is emphasized that students who have the opportunity to experience statistical process components will be statistically active and productive (NTCM, 2000). Therefore, the statistical process has a key role in making statistics teaching more effective in the GAISE report. Rumsey (2002) has emphasized to raising individuals who can manage the statistical process among the goals he stated for statistics education. Many studies point out the importance of the statistical process (Güven, Öztürk, \& Özmen, 2015; Newton, Dietiker, \& Horvath, 2011; Özmen, 2015; Rumsey, 2002; Topan, 2019; Watson, 2006). In this sense, it is clearly seen that the statistical process that includes question formulation, data collection, data analysis, and interpretation of results is important in developing students' statistical knowledge and skills (Franklin et al., 2007; Özmen, 2015; Özmen, \& Baki, 2017). These steps contribute to gaining research experience, displaying a critical approach and developing psychomotor skills (Wild, \& Pfannkuch, 1999). Hence, the statistical process emerges as one of the important factors of effective statistics teaching (Franklin et al., 2007). Taking statistical process as a basis in statistics teaching will also contribute to educators in terms of designing effective learning outcomes (Groth, 2013). In addition, it is thought that planning the statistics teaching according to the statistical process components and designing the activities in this direction will contribute to make leraning environments richer and to provide students more active. Moreover, it is predicted that the teaching designed according to the statistical process will provide the opportunity to train students as a researcher and more effective results in terms of teaching. This functional role of the statistical process has been effective in comparing curriculums in terms of the field of statistics learning. In this sense, the fields of statistics learning in the mathematics curriculums of countries were compared according to statistical process. This comparison is based on the GAISE report (Franklin et al., 2007), in that it explains the expected behaviours at different levels towards the statistical process components and includes recommendations to be taken as the basis for statistics instruction.

\subsubsection{GAISE Report}

GAISE is a report published by the American Statistical Association (ASA),includes recommendations and instructional principles for statistics education. The principles emphasized by this report also affect the whole world, but it is also important in terms of providing a broad framework for statistics instruction. In GAISE report, the main purpose of statistics instruction is to raise students as statistically literate and there are instructional suggestions in this direction. This report has focused on statistical literacy as the ultimate goal in statistics instruction, and it is emphasized that every high school graduate should be equipped with the statistical reasoning skills to lead a happy and productive life and be able to reflect this skill in daily life (Franklin et al., 2007). In addition, it has been pointed out that raising conscious and productive individuals on behalf of the society can only be possible with a good statistical education. In this sense, GAISE report provides important recommendations to teachers on how to teach statistics. This report, which is shown as a significant resource for statistics education in the world, is frequently used in the design of learning environments. The basic framework 
that build on the statistical process will make students active in statistics teaching and make statistical concepts more understandable for them. The statistical process is described as the map of a rich statistics teaching (Franklin et al., 2007). Accordingly, the statistical process in the GAISE report comprises of 4 successive components. The first one is the formulation of the problem and it is considered important in terms of starting the statistical process and directing the development of the next components. In this component, it is significant to formulate an appropriate problem and to decide on the type of data to be obtained. The second component refers to the data collection suitable for the research problem. In this component, the selection of the sample representing population, sample size and data collection methods are emphasized, and appropriate measurements are decided for the analysis. The third is the data analysis, and in this section the data can be summarized numerically or visually presented in tables and graphical representations. In the last component, appropriate inferences are made by interpreting the results obtained. In this section, the results are interpreted in their context. Meanwhile, it is thought that new problems may be formulate according to the participation of different individuals and thus it is assumed that the statistical process will have a continuity. Making sense of these components takes place depending on time and instructional practices. This developmental process is presented in the GAISE report at three levels (A, B and C) for each component, ranging from descriptive statistics to inferential statistics. In other words, the statistical process is included in the GAISE report as a framework for acquiring higher level skills based on basic skills. In this direction, at level A, it is stood out to know the basic principles of statistics and the meaning of statistical concepts; at the level $\mathrm{B}$, it is required to associate the basic statistics concepts with each other and to make comparisons over statistical situations. Finally, at level C, it is needed to generalize of the results, to know of advanced statistical concepts and their association (Franklin et al., 2007). For instance, in data collection, while determining the music group to be brought to the end-of-year school concert, A-level-students collect data with a simple experimental process by taking the opinions of their classmates. At level B, realizing that only one class will not represent the whole school, other classes are also included in the sample. Realizing that the sample should be representative of the population, students get to the level $\mathrm{C}$ when they start making random choices, assuming that everyone has an equal probability of being selected. Thus, there is a development from choices limited to one group to random selections from a large community.

The suggestions and practices of the GAISE report have an important place in determining the level of statistics teaching. It is stated that statistics teaching carried out in line with these recommendations and practices will be effective (Franklin et al., 2007). At this point, the goals and learning outcomes in the field of statistics learning in the mathematics curriculum, which form the basis for designing learning environments, stand out. It is thought that these learning outcomes will give an idea about the statistics teaching. Therefore, it is important for basing on the theoretical framework presented in this report in terms of seeing whether the curriculum constitutes a resource for more effective teaching. From this point of view, the two-dimensional theoretical structure, including the statistical process components and the three hierarchical levels, in the GAISE report (Franklin et al., 2007) is given in Table1.

Table 1. Theoretical framework in GAISE report (Franklin et al., 2007, p. 14)

$\begin{array}{llcc}\text { STATISTICAL } & \text { LEVEL A } & \text { LEVEL B } & \text { LEVEL C } \\ \text { PROCESS } & & \\ \text { COMPONENTS } & & \end{array}$

\begin{tabular}{|c|c|c|c|}
\hline $\begin{array}{c}\text { FORMULATE } \\
\text { QUESTION }\end{array}$ & $\begin{array}{c}\text { Beginning awareness of the } \\
\text { statistics question distinction } \\
\text { Teachers pose questions of interest } \\
\text { Questions restricted to the } \\
\text { classroom }\end{array}$ & $\begin{array}{l}\text { Increased awareness of the } \\
\text { statistics question distinction } \\
\text { Students begin to pose their own } \\
\text { questions of interest } \\
\text { Questions not restricted to the } \\
\text { classroom }\end{array}$ & $\begin{array}{l}\text { Students can make the statistics } \\
\text { question distinction } \\
\text { Students pose their own questions of } \\
\text { interest } \\
\text { Questions seek generalization }\end{array}$ \\
\hline $\begin{array}{c}\text { COLLECT } \\
\text { DATA }\end{array}$ & $\begin{array}{c}\text { Do not yet design for differences } \\
\text { Census of classroom } \\
\text { Simple experiment }\end{array}$ & $\begin{array}{l}\text { Beginning awareness of design for } \\
\text { differences } \\
\text { Sample surveys; begin to use } \\
\text { random selection } \\
\text { Comparative experiment; begin to } \\
\text { use random allocation }\end{array}$ & $\begin{array}{l}\text { Students make design for differences } \\
\text { Sampling designs with random } \\
\text { selection } \\
\text { Experimental designs with } \\
\text { randomization }\end{array}$ \\
\hline $\begin{array}{c}\text { ANALYZE } \\
\text { DATA }\end{array}$ & $\begin{array}{c}\text { Use particular properties of } \\
\text { distributions in the context of a } \\
\text { specific example } \\
\text { Display variability within a group } \\
\text { Compare individual to individual } \\
\text { Compare individual to group } \\
\text { Beginning awareness of group to } \\
\text { group } \\
\text { Observe association between two } \\
\text { variables }\end{array}$ & $\begin{array}{l}\text { Learn to use particular properties of } \\
\text { distributions as tools of analysis } \\
\text { Quantify variability within a group } \\
\text { Compare group to group in displays } \\
\text { Acknowledge sampling error } \\
\text { Some quantification of association; } \\
\text { simple models for association }\end{array}$ & $\begin{array}{l}\text { Understand and use distributions in } \\
\text { analysis as a global concept } \\
\text { Measure variability within a group; } \\
\text { measure variability between groups } \\
\text { Compare group to group using displays } \\
\text { and measures of variability } \\
\text { Describe and quantify sampling error } \\
\text { Quantification of association; fitting of } \\
\text { models for association }\end{array}$ \\
\hline
\end{tabular}


Table 1 continued

$\begin{aligned} & \text { INTERPRET } \\ & \text { RESULTS }\end{aligned}$
$\begin{gathered}\text { Students do not look beyond the } \\ \text { data } \\ \text { No generalization beyond the } \\ \text { classroom }\end{gathered}$
Note difference between two
individuals with different
conditions
Observe association in displays

$$
\begin{array}{cc}
\begin{array}{c}
\text { Students acknowledge that looking } \\
\text { beyond the data is feasible }
\end{array} & \begin{array}{c}
\text { Students are able to look beyond the } \\
\text { data in some contexts }
\end{array} \\
\begin{array}{c}
\text { Acknowledge that a sample may or } \\
\text { may not be representative of the } \\
\text { larger population }
\end{array} & \begin{array}{c}
\text { Generalize from sample to population } \\
\text { Aware of the effect of randomization } \\
\text { on the results of experiments }
\end{array} \\
\begin{array}{c}
\text { Note the difference between two } \\
\text { groups with different conditions }
\end{array} & \begin{array}{c}
\text { Understand the difference between } \\
\text { observational studies and experiments } \\
\text { Aware of distinction between } \\
\text { Interpret measures of strength of }
\end{array} \\
\begin{array}{c}
\text { Note differences in strength of } \\
\text { association }
\end{array} & \begin{array}{c}
\text { Interpret models of association } \\
\text { Basic interpretation of models for }
\end{array} \\
\text { Distinguish between conclusions from } \\
\text { association studies and experiments }
\end{array}
$$
association

Aware of the distinction between

association and cause and effect

In the GAISE report, it is stated that individuals' experiences of the statistical process have an important place to be a qualified statistical literate. At this point, it has been indicated that educators and program developers should design practices that will enable students to experience the statistical process. In this way, the trend of statistics in recent years and the emphasis of GAISE reports on qualified statistics teaching have enabled many countries to innovate in the mathematics curriculum. Within the scope of innovation studies, the fact that countries have included statistics at different densities in their curriculum has paved the way for some countries to come into prominence in statistical education. For this reason, comparative analysis of different countries' curriculum enables countries to see their strengths and weaknesses for educational activities and to integrate effective practices into their own systems. When the literature has been examined, there are many studies on comparing the mathematics curriculums of countries (Altıntaş, \& Görgen, 2014; Çelik, Kul, \& Çalık-Uzun, 2018; Erbilgin, 2014; Erdoğan, Hamurcu, \& Yesiloğlu, 2016; Güzel, Karataş, \& Çetinkaya, 2010; İncikabi, \& Tuna, 2012; Kaytan, 2007; Kul, \& Aksu, 2016; Özkan, 2006; Özreçberoğlu, \& Kıvanç-Çağanağa, 2016). In these studies, mathematics curriculums were compared in a way to cover substantially all learning fields by stating the general characteristics and objectives of the curriculums. However, there are also studies to compare the mathematics curriculums of countries in terms of a specific learning field (Arık, 2007; Tezcan, 2016; UğurArslan, 2015). In these studies, the mathematics curriculums were examined for learning fields such as numbers, algebra, and geometry, but it is seen that there have been no studies directly on the statistics learning field. Hence, it is revealed the need to examine different countries in terms of the statistics learning field and to compare them according to similarities and differences. The fact that the GAISE report is an important resource for statistics education and how or to what extent the educational principles and practices pointed out in the GAISE report are based on the curriculums of countries have important roles in making these comparisons. Considering that the curriculum shaped by the report will be the starting point of effective statistics teaching, it is considered that the curriculums of the countries should be examined in terms of similarities and differences in terms of the field of statistics learning in accordance with this report. At this point, comparing the curriculums on the basis of statistics and making the necessary arrangements in the curriculum depending on the results will provide the opportunity to make the necessary changes for students to be statistically equipped. In the present study, it is aimed to examine Turkey with Singapore, Korea, USA and New Zealand mathematics curriculums in terms of the field of statistics learning according to the GAISE report (Franklin et al., 2007) and to compare the tendency of the learning outcomes according to the theoretical framework presented in the report. Depending on this main purpose, the research questions were determined as follows:

$>$ How learning outcomes of the field of statistics learning of countries differ in terms of the developmental levels presented in the GAISE report?

$>$ How learning outcomes of the field of statistics learning of countries differ in terms of statistical process components presented in the GAISE report?

\section{Method}

This study is a comparative research that intends to compare Turkey to Turkey, Singapore, Korea, USAUSA and New Zealand in terms of the field of statistics learning in the mathematics curriculums. Document analysis method, which is of qualitative research patterns, is used for presenting curriculum of the countries in this study. The mathematics curriculums of the five countries have been analysed in accordance with the objective of the study and the theoretical framework defined within GAISE report.

\subsection{Countries Involved in the Study}

Two criteria are used to determine the countries to be included in the study.. The first one is that it is emphasized to take place near the top at exams of Trends in International Mathematics and Science Study (TIMSS) which is implemented as an assessment exam with the aim of monitoring education systems of 
countries and Programme for International Student Assessment (PISA) which emphasizes on students' ability to use knowledge and skills they learn in school in daily life. Singapore and Korea have been chosen to be involved in the study among the countries that are succeed in the PISA (2015) and TIMSS (2015) exams. Secondly, USA (Lovett, \& Lee, 2018; Newton, Dietiker, \& Horvath, 2011) and New Zealand (Burgess, 2007; Forbes, 2014) have been preferred among the countries that have come to the fore with their recent studies in the field of statistics.

\subsection{Data Collection and Analysis}

Learning outcomes (content, standard, goal) regarding the field of statistics learning in the curriculum of the countries are analysed in line with levels (A, B, and C) specified for statistical process components of GAISE Report. The curriculums analysed within the study (upgrading year is 2018 for Turkey, 2013 in primary and secondary grade and 2016 in H1, H2 and H2 Forward (H2F is qualified as $13^{\text {th }}$ grade) grade for Singapore, 2015 for Korea, 2012 for USA and 2012 for New Zealand) include primary, secondary and high school mathematics curriculums in accordance with K-12 specified in GAISE Report. Learning outcomes and explanations in curriculums are evaluated within the context of the aspects regarding A, B and C levels in statistical process components defined in the theoretical framework. As classifying statistics learning outcomes taking place in curriculums according to their related component and levels, in case of the fact a learning outcome has an explanation related to more than one statistical process component related learning outcome takes place in both components. These kinds of learning outcomes are written clearly in the first component that is included (learning outcome number and label) and only the number of the learning outcome is specified in other components. Where a learning outcome is suitable for more than one level, it is written at the highest level that it can go up to prevent such repetitive situations to occur. Analysis process is shown on an example in Table 2.

Table 2. An example analysis of the learning outcomes in the theoretical framework (Singapore example)

\begin{tabular}{|c|c|c|c|}
\hline $\begin{array}{l}\text { STATISTICAL } \\
\text { PROCESS } \\
\text { COMPONENT }\end{array}$ & LEVEL A & LEVEL B & LEVEL C \\
\hline \multicolumn{4}{|l|}{$\begin{array}{c}\text { FORMULATE } \\
\text { QUESTION }\end{array}$} \\
\hline $\begin{array}{c}\text { COLLECT } \\
\text { DATA }\end{array}$ & $\begin{array}{l}\text { SO1.2. Work collaboratively } \\
\text { on a task to: collect and } \\
\text { classify data, present data } \\
\text { using an appropriate statistical } \\
\text { representation (including the } \\
\text { use of software), analyze data }\end{array}$ & & \\
\hline $\begin{array}{c}\text { ANALYZE } \\
\text { DATA }\end{array}$ & (SO1.2.) & $\begin{array}{l}\text { P4.3. Construct a line graph using a } \\
\text { spreadsheet e.g. Excel, and make } \\
\text { connections between bar and line graphs, } \\
\text { and explain which type of graph should } \\
\text { be used or both can be used. }\end{array}$ & \\
\hline $\begin{array}{l}\text { INTERPRET } \\
\text { RESULTS }\end{array}$ & & & \\
\hline
\end{tabular}

(P: Primary education level 1-6, SO: Secondary education level curriculum-related learning outcomes)

As analysing the Table 2, SO1.2 learning outcome in secondary education level in Singapore includes expressions regarding data collection and data analysis. Due to the fact that the expression of the learning outcome is required to use basic knowledge directly, it is limited with aspects specified in Level A for both components. P4.3 learning outcome of $4^{\text {th }}$ grade of primary education includes a target behaviour toward Level A due to requiring students to do calculations at a basic level by taking features of line graph for a certain statistical question. In the continuation of the learning outcome, expressions regarding Level B such as relating between bar and line graphs and determining which graph to be used in case of statistical situation by comparing these two graph types take place. Consequently, this learning outcome is evaluated to be included in Level B.

The stages suggested by Forster (1995) are conceived while examining the document. Firstly, a detailed research was carried out to reach first-hand mathematics curriculums used as document. Secondly, the originality of the accessed curriculums was checked by taking into consideration that it is located on the page of the Ministry of Education of the country to which it belongs. Then, the aims and objectives of them for general and mathematics teaching were examined to understand the curriculums. In this direction, the processes of understanding and analysing the statistics learning outcomes have been started. In the fourth stage, the outcomes are analysed in line with the theoretical framework included in the GAISE report. A common analysis procedure related to analysis of learning outcomes regarding in the field of statistics learning of the countries was followed. Firstly, statistical process component and expected behaviours in three levels for every component were analysed 
in detail in GAISE report. It was discussed on situations differentiating each component and level from another and their scope is revealed. Thus, it was enabled to initiate a common analysis procedure. Following determining the procedure concerning the analysis, statistics learning outcomes in a mathematics curriculum of a country were analysed by all researchers. In the analysis, firstly, the statistical process component to which a learning outcome is related, and then its level were determined.Through process of decision making, it is discussed and discussions are continued until reaching a common idea over theoretical framework related to GAISE report in case of any dispute. Thereafter every researcher have analyzed learning outcomes of a country in accordance with common analysis procedure that is determined. To ensure the reliability of these analyses, attention is paid to ensure that all researchers work in the field of statistics education and are close to the research field. Following the completion of the analysis, descriptive analysis were applied for classifying learning outcomes regarding the field of statistics learning in the mathematics curriculum of a country on the aspect of related statistical process component and level. After the researchers completed the coding process, descriptive analysis were performed. Researchers re-encoded and confirmed whether the results reflect the reality. The data obtained at the last stage of the analysis process have been presented with the help of frequencies and percentages. In the last stage, the analysis results are interpreted in line with the research problems.

\section{Findings}

Learning outcomes regarding in the field of statistics learning in the mathematics curriculum of the countries are analysed by using theoretical framework presented by GAISE report. Firstly, learning outcomes included in mathematics curriculum of countries are evaluated according to hierarchical levels presented by theoretical framework. Following this, the distribution of the learning outcomes associated with the levels in terms of statistical process components is included.

Distribution of related levels (A, B and C) of statistics learning outcomes included in mathematics curriculum of the countries are shown in Graph 1.

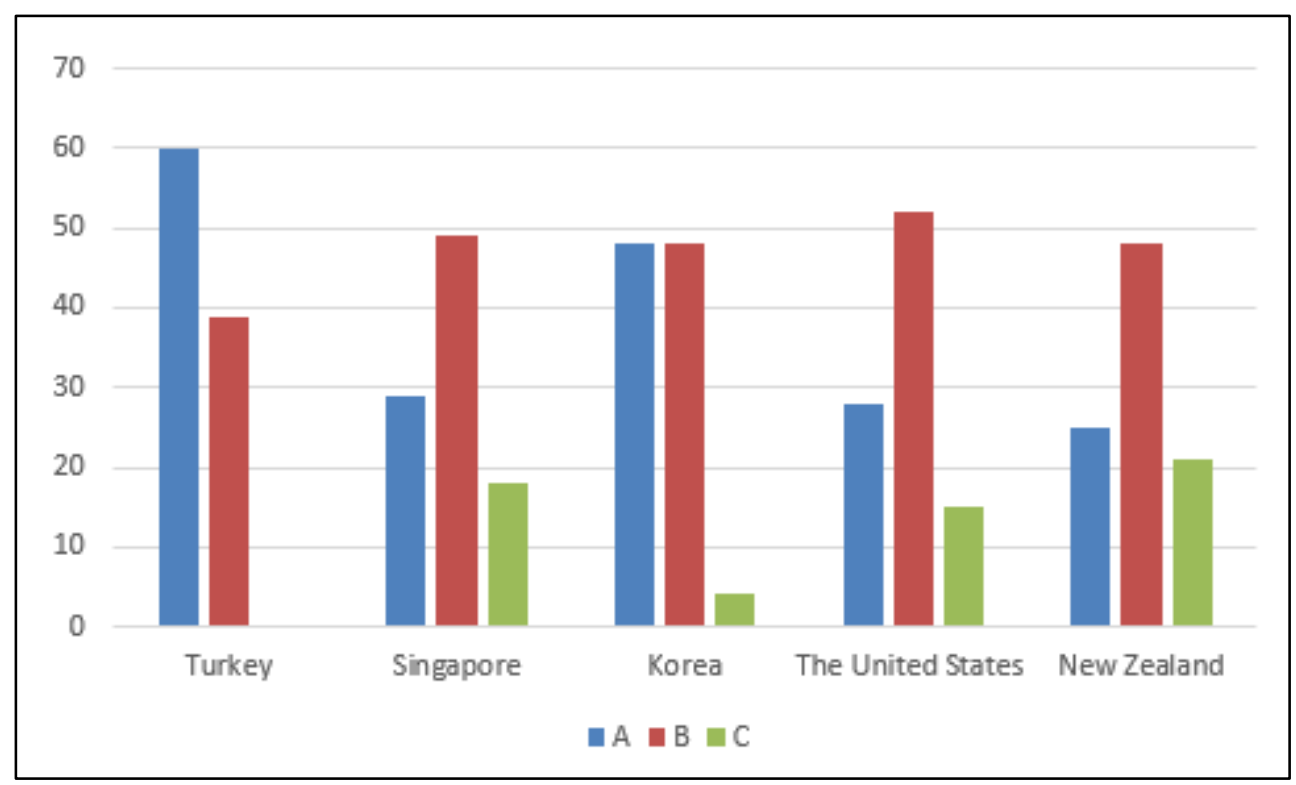

Graph 1. Distribution of statistics learning outcomes of countries by A, B and C levels (\%)* *Calculations have been made taking into account all the learning outcomes of the countries in the field of statistics learning.

As looking into Graph 1, it has been shown that learning outcomes at level B and C, requiring higher-level of statistical knowledge and skills are intensified at Singapore and New Zealand, USA and Korea include learning outcomes at such levels in their mathematics curriculum as well. In Turkey, it is seen that learning outcomes related to the field of statistics learning that is included in mathematics curriculum go up to Level B at most and no learning outcomes are at Level $\mathrm{C}$. Aside from the fact that the ratio of learning outcomes regarding Level A requiring statistics knowledge at more basic level is seen to be more, this ratio points up to be higher than the ratio of other countries. While the ratio of learning outcomes regarding Level B is higher in Singapore, New Zealand, and USA the ratio of learning outcomes regarding Level A and B are equal and are more than C level in Korea.

The weight given to the field of statistics learning in mathematics curriculum of the countries and results (in frequency and percentage) regarding accordance with Level A, B and C of statistical process components associated with learning outcomes in this field are included in Table 3. 
Tablo 3. Distribution of the learning outcomes of the countries in the statistical process components in terms of A, B and C levels.

\begin{tabular}{|c|c|c|c|c|c|c|c|c|c|c|c|c|c|c|c|c|c|c|c|c|c|}
\hline \multirow{3}{*}{$\begin{array}{l}\text { STATISTICAL } \\
\text { PROCESS } \\
\text { COMPONENT }\end{array}$} & \multicolumn{20}{|c|}{ COUNTRIES } & \multirow{3}{*}{$\begin{array}{c}\text { Overal } \\
\text { Total }\end{array}$} \\
\hline & \multicolumn{3}{|c|}{ TURKEY } & \multirow[t]{2}{*}{ Total } & \multicolumn{3}{|c|}{ SINGAPORE } & \multirow[t]{2}{*}{ Total } & \multicolumn{3}{|c|}{ KOREA } & \multirow[t]{2}{*}{ Total } & \multicolumn{3}{|c|}{$\begin{array}{c}\text { THE UNITED } \\
\text { STATES }\end{array}$} & \multirow[t]{2}{*}{ Total } & \multicolumn{3}{|c|}{ NEW ZEALAND } & \multirow[t]{2}{*}{ Total } & \\
\hline & $\mathbf{A}$ & B & $\mathbf{C}$ & & $\mathbf{A}$ & B & $\mathbf{C}$ & & $\mathbf{A}$ & B & $\mathbf{C}$ & & $\mathbf{A}$ & B & $\mathbf{C}$ & & $\mathbf{A}$ & B & $\mathbf{C}$ & & \\
\hline $\begin{array}{l}\text { FORMULATE } \\
\text { QUESTION }\end{array}$ & $\begin{array}{c}* 1 \\
(3 \%)\end{array}$ & $\begin{array}{c}1 \\
(3 \%)\end{array}$ & - & $\begin{array}{c}* * 2 \\
(13 \%)\end{array}$ & - & $\begin{array}{c}1 \\
(1 \%)\end{array}$ & - & $\begin{array}{c}1 \\
(7 \%)\end{array}$ & - & - & - & - & $\begin{array}{c}2 \\
(4 \%)\end{array}$ & - & - & $\begin{array}{c}2 \\
(13 \%)\end{array}$ & $\begin{array}{c}3 \\
(3 \%)\end{array}$ & $\begin{array}{c}5 \\
(5 \%)\end{array}$ & $\begin{array}{c}2 \\
(2 \%)\end{array}$ & $\begin{array}{c}10 \\
(67 \%)\end{array}$ & $\begin{array}{l}* * * 15 \\
(6 \%)\end{array}$ \\
\hline $\begin{array}{l}\text { COLLECT } \\
\text { DATA }\end{array}$ & $\begin{array}{c}2 \\
(6 \%)\end{array}$ & $\begin{array}{c}2 \\
(6 \%)\end{array}$ & - & $\begin{array}{c}4 \\
(11 \%)\end{array}$ & $\begin{array}{c}4 \\
(6 \%)\end{array}$ & $\begin{array}{c}1 \\
(1 \%)\end{array}$ & $\begin{array}{c}1 \\
(1 \%)\end{array}$ & $\begin{array}{c}6 \\
(17 \%)\end{array}$ & $\begin{array}{c}3 \\
(12 \%)\end{array}$ & $\begin{array}{c}1 \\
(4 \%)\end{array}$ & - & $\begin{array}{c}4 \\
(11 \%)\end{array}$ & - & $\begin{array}{c}1 \\
(2 \%)\end{array}$ & $\begin{array}{c}2 \\
(4 \%)\end{array}$ & $\begin{array}{c}3 \\
(8 \%)\end{array}$ & $\begin{array}{c}4 \\
(4 \%)\end{array}$ & $\begin{array}{c}8 \\
(9 \%)\end{array}$ & $\begin{array}{c}7 \\
(8 \%)\end{array}$ & $\begin{array}{c}19 \\
(53 \%)\end{array}$ & $\begin{array}{c}36 \\
(14 \%)\end{array}$ \\
\hline $\begin{array}{l}\text { ANALYZE } \\
\text { DATA }\end{array}$ & $\begin{array}{c}14 \\
(42 \%)\end{array}$ & $\begin{array}{c}10 \\
(30 \%)\end{array}$ & - & $\begin{array}{c}24 \\
(15 \%)\end{array}$ & $\begin{array}{c}13 \\
(20 \%)\end{array}$ & $\begin{array}{c}30 \\
(46 \%)\end{array}$ & $\begin{array}{c}11 \\
(17 \%)\end{array}$ & $\begin{array}{c}54 \\
(32 \%)\end{array}$ & $\begin{array}{c}9 \\
(36 \%)\end{array}$ & $\begin{array}{c}11 \\
(44 \%)\end{array}$ & $\begin{array}{c}1 \\
(4 \%)\end{array}$ & $\begin{array}{c}21 \\
(13 \%)\end{array}$ & $\begin{array}{c}6 \\
(13 \%)\end{array}$ & $\begin{array}{c}13 \\
(30 \%)\end{array}$ & $\begin{array}{c}5 \\
(11 \%)\end{array}$ & $\begin{array}{c}24 \\
(15 \%)\end{array}$ & $\begin{array}{c}15 \\
(17 \%)\end{array}$ & $\begin{array}{c}23 \\
(27 \%)\end{array}$ & $\begin{array}{c}4 \\
(4 \%)\end{array}$ & $\begin{array}{c}43 \\
(25 \%)\end{array}$ & $\begin{array}{c}165 \\
(66 \%)\end{array}$ \\
\hline $\begin{array}{l}\text { INTERPRET } \\
\text { RESULTS }\end{array}$ & $\begin{array}{c}3 \\
(9 \%)\end{array}$ & - & - & $\begin{array}{c}3 \\
(9 \%)\end{array}$ & $\begin{array}{c}2 \\
(3 \%)\end{array}$ & $\begin{array}{c}1 \\
(1 \%)\end{array}$ & - & $\begin{array}{c}3 \\
(9 \%)\end{array}$ & - & - & - & - & $\begin{array}{c}5 \\
(11 \%)\end{array}$ & $\begin{array}{c}9 \\
(20 \%)\end{array}$ & - & $\begin{array}{c}14 \\
(42 \%)\end{array}$ & $\begin{array}{c}1 \\
(1 \%)\end{array}$ & $\begin{array}{c}6 \\
(7 \%)\end{array}$ & $\begin{array}{c}6 \\
(7 \%)\end{array}$ & $\begin{array}{c}13 \\
(40 \%)\end{array}$ & $\begin{array}{c}33 \\
(\mathbf{1 3} \%)\end{array}$ \\
\hline $\begin{array}{l}\text { Weight of the } \\
\text { field of statistics } \\
\text { learning }\end{array}$ & & $\begin{array}{l}* * * * 33 \\
(6 \%)\end{array}$ & & 574 & & $\begin{array}{c}64 \\
(10 \%)\end{array}$ & & 632 & & $\begin{array}{c}25 \\
(5 \%)\end{array}$ & & 467 & & $\begin{array}{c}43 \\
(12 \%)\end{array}$ & & 347 & & $\begin{array}{c}84 \\
(30 \%)\end{array}$ & & 275 & \\
\hline
\end{tabular}

Note: Expressions represented by ratios in the table are explained over examples given for any situation so as not to be confused.

*Related ratio is acquired by dividing the number of learning outcomes regarding related component and levels of countries into total number of learning outcomes related to the field of statistics learning in mathematics curriculum.

(Exp: Having 33 statistics learning outcomes in total and 1 learning outcome belonged to Level A at the component of formulate question in Turkey, the ratio is calculated as $3 \%$.)

$* *$ Related ratio is acquired by dividing total number of learning outcomes that every country has included regarding related statistical process component into total number of learning outcomes of all countries for the component.

(Exp: By having 15 learning outcomes in total regarding the component of formulate question included in curriculum of all countries and Turkey having 2 learning outcomes belonged to this component, the ratio is calculated as $13 \%$.)

***Related ratio is acquired by dividing total number of learning outcomes regarding a certain statistical process component in general into total number of learning outcomes included in all components.

(Exp: By having total number of 549 learning outcomes regarding statistical process component and 15 of these learning outcomes belonging to the component of formulate question, the ratio is calculated as 6\%.)

****Related ratio is acquired by dividing total number of learning outcomes related to the field of statistics learning each country into total number of learning outcomes included in mathematics curriculum of each country.

(Exp: By having 574 learning outcomes in mathematics curriculum of Turkey and 33 of these learning outcomes belonging to the field of statistics learning, the ratio is calculated as 6\%.) 
As looking into Table 3, the number of learning outcomes related to the field of statistics learning in mathematics curriculum of New Zealand is shown to be higher among all countries. Besides, comparing the ratios of statistics learning outcomes, New Zealand is noted to have the highest ratio (30\%). Despite Singapore being the second on the aspect of total number of statistics learning outcomes, it is shown to come the third (10\%) following USA (12\%) on the aspect of proportion of statistics learning outcomes. Furthermore, Korea has the least learning outcomes related to the field of statistics learning. Aside from Turkey having more learning outcomes in number than Korea. Korea (5\%) and Turkey $(6 \%)$ have almost the same percentage on the aspect of the weight of learning outcomes in curriculum. Consequently, it is seen that Korea and Turkey have weaker profiles in comparison of other countries on the aspect of both the number and the weight of statistics learning outcomes in curriculum.

When analysed on the aspect of statistical process components and related levels of learning outcomes in Table 3, there are more learning outcomes at Level A and B at every component in general. Moreover, the higher amount of learning outcomes regarding the component of data analysis is pointed out. The number of learning outcomes regarding this component in curriculum of all countries to be spared is noted to be higher. The number of learning outcome for this component is $66 \%$ of total number of learning outcomes in all components. It has been shown that data analysis has the highest learning outcomes reflecting each level in all other components. It is noted that all countries have more learning outcomes at Level B in data analysis and Singapore is prominent on this component. Singapore includes more learning outcomes regarding this component with the ratio of $32 \%$ in comparison of other countries and $83 \%$ of them belong to the component of data analysis. Furthermore, $46 \%$ of them are at Level B, while Singapore has the highest percentage (17\%) in terms of learning outcomes at Level $\mathrm{C}$ as well. For example, in Singapore, understandings related to inferential statistics subjects such as sampling methods, sampling distribution, confidence interval, hypothesis testing, correlation, regression and least squares method are prominent regarding Level $\mathrm{C}$ in data analysis in $\mathrm{H} 1, \mathrm{H} 2$ and $\mathrm{H} 2 \mathrm{~F}$ mathematics curriculum which is presented as elective course during the period following the secondary education and pre-university. The subjects included in the curriculum of the countries, grade levels that these subjects and a total number of learning outcomes within these grade levels are given in Appendix 2. Besides, learning outcomes such as H4.4 (meaning of correlation), HF1.6 (confidence interval), H3.3 (hypothesis testing) are regarding subject and concept of inferential statistics (look at Appendix 1-Table 6). Turkey is shown to be prominent on the aspect of including learning outcomes related to Level $\mathrm{A}$ in data analysis. In fact, learning outcomes related to this component and level in curriculum of Turkey are given much more weight in comparison of other countries (44\%). However, it is detected that subjects of inferential statistics or any learning outcomes that can be a basis for these subjects are not included in Turkey. Thus, it is shown that no learning outcome at Level $\mathrm{C}$ is available in curriculum of Turkey. Despite of the fact that Korea, USA and New Zealand have more learning outcomes in number regarding the component of data analysis, learning outcomes related to Level $\mathrm{C}$ emphasizing on inferential statistics such as normal distribution, correlation, regression, hypothesis testing and confidence interval are noted to be included finitely in these countries. For example, in Korea, subjects of inferential statistics are limited with understanding of normal distribution by including only L.9.5 (meaning of normal distribution) regarding inferential statistics at level of high school (look at Appendix 1 -Table 9). Besides, learning outcomes related to question formulation which is the most important component for initiating procedure of statistical research and planning correctly are found to be included in less ratio in all countries. Thus, it is noticed that the ratio of learning outcomes regarding this component $(6 \%)$ is the least in all components. As Korea doesn't have any learning outcomes regarding this component, few learning outcomes in Level A and B are included in Singapore, USA and Turkey. Having limited learning outcomes regarding this component in these countries and not including learning outcomes concerning Level $\mathrm{C}$ which questions further understanding is thought as limitedness for the component of question formulation to be the first step of statistical process. Thus, as New Zealand includes more space for the component of question formulation with a ratio of $67 \%$, learning outcomes reflecting Level $\mathrm{C}$ are found to be included in this country. Many learning outcomes regarding question formulation such as formulating the problem by using statistical process, formulating research questions based on relating and comparing and searching different and independent problems are found in New Zealand. Additionally, learning outcomes regarding component of the interpretation of the results which enables students to infer and think critically are fewer in all countries and this component is seen to follow the component of formulating question. It is noted that the ratio of the number of learning outcomes regarding this component in all components is $13 \%$ and these learning outcomes are centered upon in Level B in general. In comparison of other countries, USA includes more learning outcomes regarding component of interpretating results with a ratio of $42 \%$. USA gives more emphasis on learning outcomes regarding this component on the aspect of Level A (11\%) and Level B (20\%) as compared to other countries. In USA, these two levels in interpretation of results are presented with subjects such as summarization of data, interpretation of table and graphs, and basic inferring based on correlation coefficients. For example, HSS.ID.C.8 (interpretion correlation coefficient) learning outcome is shown to be related to Level B on the aspect of interpreting the strength of relation between specified variables and putting forth situation of variables according to each other; HSS.IC.B.6 (interpretation of data) learning outcome requires interpretations at basic 
level to be expressed by giving obvious data set and it is in accordance with aspects of Level A (look at Appendix 1- Table 7). Whereas no learning outcome concerning this component is included in Korea, interpretation of results is limited with Level A in Turkey.. As USA does not have any learning outcomes at Level C concerning this component, New Zealand spares $7 \%$ of its curriculum for Level C. For example, as different from USA, L5.3.1.1 (comparison of sampling distribution) learning outcome includes objectional behaviour concerning Level $\mathrm{C}$ regarding sampling distribution. Inferential statistics such as estimating situations that may occur within the separate data set by using these data set (interpolation) and making forward looking inference outside of given data set (extrapolation) are included more in detail. As a result, learning outcomes related to Level $\mathrm{B}$ and $\mathrm{C}$ such as making prediction, detecting sampling error and estimating for average by central limit theorem are more in number. Another example, as L7.2.1.2.b (estimation of population parameter) learning outcome relates to Level $\mathrm{C}$ requiring beyond data literacy and generalisation, it includes L7.2.2.1.b (detection of sampling error) learning outcome associated with Level B in which comparisons among groups are made dominantly in making sampling to reflect a certain statistical situation as well (look at Appendix 1- Table 8). On the other hand, the number of learning outcomes at all three levels is almost equally included at the component of data collection.. In this sense, distribution of learning outcomes to all levels is the most balanced at the component of data collection. Learning outcomes belonged to this component have $14 \%$ percentage within the statistical process components. Whereas no learning outcome reflecting Level A in this component is found in USA, any learning outcomes related to Level C regarding this component are not found in Turkey and Korea. Singapore represents Level C with only one learning outcome H2.1 (choosing random sampling) included in $\mathrm{H} 2$ mathematics curriculum and in which the relation of population and sampling is evaluated in the focus of concept of randomness (look at Appendix 1- Table 6). However, New Zealand gives more emphasis on the component of data collection with the ratio of 53\% in comparison of other countries. It is prominent on the aspect of reflecting this component with learning outcomes at Level A and B as well. It is shown that the importance given to both these levels within the component (B: $9 \%$ and C: $8 \%$ ) is more than other countries. New Zealand gives subjects and concepts that are to set an example to Level B and C such as data set with many variables, random choices, representability, limitedness of choices of sampling and experimental designs. For example, 8.3.1.1 (producing data sets) learning outcome is addressed as related to Level B due to this learning outcome requiring new data sets to be produced as result of relating many variables; L7.2.1.1.a (experimental designs based on random sampling) learning outcome reflects Level $\mathrm{C}$ on the aspect of making sense of randomness concept (look at Appendix 1-Table 8). Tables belonging to each country presenting distribution of learning outcomes given as frequency and percentage in Table 3 on the aspect of contents are given in Appendix 1. The number of learning outcomes is indicated in the tables and access addresses of websites covering their contents are given.

\section{Discussion and Conclusion}

The components, starting with formulating a problem, continuing with collecting data, analysingrepresentation data and inferring from data forms the basis of statistical literacy (Watson, 2006). It is also stressed that handling the components of the statistical process with a holistic approach is significant in students' experiencing more effective statistics teaching (Newton, Dietiker, \& Horvath, 2011). In this way, handling the statistical process, that helps us to provide active participation and more effective management of the process, with a holistic approach (following each component hierarchically) has an important role. It is not enough to integrate our statistics teaching activities related statistical process, but it is also important to design learning environment with these activities in a way that will provide a basis for effective and permanent statistics teaching (Franklin et al., 2007). Besides, analysis based on the theoretical framework pointed out in GAISE report has an important role on determining the tendency of the curriculums that forms the statistics teaching. In this way, the statistics learning outcomes in mathematics curriculum of countries were analysed through the reflection of the statistical process which is seen as an important for GAISE report.The research results have shown that number of the statistics learning outcomes in math curriculum and the level of these learning outcomes in Turkey was lower than other countries. Although the learning outcomes are only related to Level A and B in our country, other countries have more learning outcomes related to Level B and C. Especially Singapore and New Zealand come to the forefront in this sense. It is also thought that this result could reflect the fact the achievement of PISA and TIMSS exams for these countries. Nevertheless, it is an important fact that Turkish students have lower success compared to other countries for the problems requiring determining the literacy, reasoning levels related to the field of statistics learning (PISA, 2015; TIMSS, 2015). One of the reasons for this failure could be raised to give more emphasis on basic statistics knowledge rather than statistical literacy at statistics subjects and learning outcomes in our curriculum. It is suggested that more emphasis on Level B and C learning outcomes and inferential statistics subjects should be place in our mathematics curriculum like other countries. Although there is an increase about the research on statistical literacy, reasoning and thinking in our country, a common result of the research is about the insufficiencies of the students, teachers or individuals in terms of the statistical literacy (Koparan, 2012; Özmen, 2015; Reston 2005). In this way, these results will only make sense if there is an attempt to enhance the curriculum and later statistics teaching. Otherwise, research would be limited to 
picture the current situation. In this way, studies about incorporating the learning outcomes related to the higher level emphasized in the GAISE report would be an important attempt.

When the distribution of the learning outcomes related to the field of statistics learning according to the statistical process components across countries is examined, it is seen that there is less emphasis on the components of formulating the problem and the interpretation of the results, and more emphasis on the component of data analysis. The nature of the data analysis requires to summarize the data set by the help of the different measurements and representations. This could be effective on this result. Similarly, research on statistical process, data analysis and representation component are forefront whileformulating the problem and interpreting the data components are generally ignored (Koparan, \& Güven, 2013; Money, 2002). In this way, carrying out research on these components and making necessary improvements on curriculums depending on this research results should be an important attempt. Representation of the data with the proper way and analysing data following the appropriate methods are important aspects of statistical literacy (Steen, 1999). But it is also of great importance to formulate an appropriate problem that will start the process for resorting to such representations and analyses and to critically evaluate and interpret the results. On the other hand, formulating the problem is the first component of the statistical process and has a crucial importance to continue the following steps correctly. Therefore, having not enough knowledge about this component or being unsuccessful at formulating an effective problem would affect continuing components. In this way, learning outcomes related to formulating the problem and interpretation of what kind of results would emerge on referring problems fit or not with the purpose should integrate the curriculums. Otherwise, interpretation of the results is an important component for evaluating the obtained results, the failure about this component could be a barrier to discuss on different ideas or interpretations, and this would also negatively affect the cyclical structure of the statistical process. The fact that the number of learning outcomes included in the mathematics curriculums of countries is not considered to mainly reflect each component of the statistical process may cause obstacles to the full understanding of these components by students. It will also raise problem about the experiencing the statistical process, is one of the important aspects of the statistical literacy. Therefore, giving place learning outcomes for each component of statistical process in our mathematics curriculum is an initial attempt to overcome these problems.

Differences about the number and content of the learning outcomes across countries are seen one of the important factors for determining the statistical knowledge and skills of the students. For example, statistics learning outcomes in Singapore mathematics curriculum are more than and based on the structure that is starting with basic concepts and extending inferential statistics, on the other hand the number of the statistics learning outcomes in our mathematics curriculum is less and related with lower levels. It is thought that these differences are effective on determining the success of the countries for the statistics field. Following a structure from basic concepts to inferential statistics and having enough learning outcomes for this structure should be an important factor to obtain important outcomes and to emerge different achievement level between countries. Thus, it is also thought that students, raising as following this kind of structure, have higher skills as reasoning, argument, critical thinking. For example, raising students as having the enough knowledge at the concept of the relationship between variables at school level, it could be helpful to interpret and to make sense of the relationship between variables related to correlation and regression subjects at university level. When students have enough knowledge about the big ideas (significant difference) as a basis for further concepts such as confidence interval and hypothesis testing, would be helpful at making the meaningful understanding related formulating the hypothesis, testing this hypothesis with a confidence level and justifying about the hypothesis. Therefore, it is important for individuals to take decisions related their daily and professional lives through statistical process rather than leaving these decisions to chance. It is also stated that students who can handle their statistical knowledge as embedded in the components of the statistical process will also be trained as a good problem solvers (Neumann, Hood, \& Neumann, 2013). In this sense, giving place on the learning outcomes as a basis for inferential statistics in the field of statistics learning in the mathematics curriculums would be an important attempt for statistics education.

In our country, dealing with statistics in a narrower scope in the mathematics curriculum is seen as the biggest precursor of the difficulty for students, to be able to statistically evaluate the situations that they will encounter in their life. Statistics, which is one of the leading roles of today's world surrounded by data involves much more than basic concepts such as average, standard deviation, graphs (bar, line, pie chart etc.). In this way, it is also important to design statistics teaching as building on statistical process and concentrating on statistical literacy, thinking, and reasoning skills to provide more qualified and effective teaching related to the field of statistics learning. However, number and content of the learning outcomes are not enough potential to meet the requests regarding the field of statistics learning in our mathematics curriculum. Thus, it is stated that it will be difficult to raise students as productive consumer of the statistical data by the help of the current learning outcomes in our curriculum, mostly Level A and B (Koparan, 2012; Yolcu, 2012). In order to cope with these difficulties, it is suggested to increase the number of the learning outcomes and to be arranged their content that will allow to the development of skills such as reasoning, argument and critical thinking as referring to basic 
knowledge and ideas on statistics. Besides, research on statistics education also stressed that the quality of statistics teaching should be enhanced, and skills considered important should be developed for students (Akoğlu, 2018; Chick, \& Pierce, 2008; Garfield, \& delMas, 2010). It is obvious that the importance of including learning outcomes for Level $\mathrm{C}$ in the development of necessary knowledge and skills expected from students. It is not possible to expect to raise students as equipped with the statistical literacy and thinking skills required by our age by the help of the current mathematics curriculum which has limited with Level A and B. In this way, to achieve the goal of raising students as statistically literate it is suggested to enrich the curriculum with the learning outcomes build on each component and level. It will be an important attempt to arrange our curriculum in this direction for the goal of raising more qualified individuals after statistics teaching. To raise students as equipped with the statistical literacy, thinking and reasoning skills, the importance of the proper statistics teaching is mentioned (Callingham, \& Watson, 2017; Groth, 2017; Özmen, \& Baki, 2017). Besides curriculum plays an important role on designing the mathematics teaching, classroom practices. As a matter of fact, although curriculum involves the higher-level topics and learning outcomes, it is the teacher who will apply it. This also points out that attention should be drawn to statistics teaching. Besides, limited topics and practices related to the field of statistics learning, it is also stated that teachers are inadequate or feel inadequate themselves for statistics teaching. In this sense, firstly, it is recommended to review and enhance the field of statistics learning in the mathematics curriculum in our country. Later, in line with the renewed curriculum, studies can be carried out to improve statistics teaching and, accordingly, to examine the outputs in line with the ultimate goals for statistics education.

There are some limitations in this study, which aims to compare mathematics curriculums of different countries in terms of the field of statistics learning. Present study, learning outcomes in the field of statistics learning in mathematics curriculums of countries were analysed through the theoretical framework presented in GAISE report based on the statement and their explanations mentioned in the curriculum. Due to this limitation, it is not mainly understood that how the statistics teaching design in these countries. In this context, it is suggested to carry out research on examining the textbooks or observing statistics teaching in learning environment for these countries and to make more detailed comparisons. Moreover, reviewing our curriculum based on these research results will also contribute to obtain more effective learning outcomes.

\section{APPENDIX 1}

Table 5. Distribution of statistics learning outcomes in Turkey (see http://www.meb.gov.tr/)

\begin{tabular}{|c|c|c|c|}
\hline $\begin{array}{l}\text { STATISTICAL PROCESS } \\
\text { COMPONENT }\end{array}$ & LEVEL A & LEVEL B & LEVEL C \\
\hline $\begin{array}{l}\text { FORMULATE } \\
\text { QUESTION }\end{array}$ & M.5.3.1.1. & M.6.4.1.1. & - \\
\hline $\begin{array}{l}\text { COLLECT } \\
\text { DATA }\end{array}$ & M.2.4.1.1. M.5.3.1.2. & M.4.4.1.3 (M.6.4.1.1.) & - \\
\hline $\begin{array}{c}\text { ANALYZE } \\
\text { DATA }\end{array}$ & $\begin{array}{l}\text { M.1.4.1.1. M.3.4.1.3. M.4.4.1.2. } \\
\text { M.5.3.1.3. M.6.4.1.2. M.6.4.2.1. } \\
\text { M.6.4.2.2. M.7.4.1.1. M.8.4.1.1. } \\
\text { (M.2.4.1.1 M.5.3.1.2 M.9.5.1.1.) } \\
\text { M.4.4.1.4. }\end{array}$ & $\begin{array}{c}\text { M.3.4.1.1.M.3.4.1.2.-M.6.4.2.3. } \\
\text { M.7.4.1.2.-M.7.4.1.3.M.7.4.1.4. } \\
\text { M.8.4.1.2.-M.9.5.2.2.(M.4.4.1.3.) }\end{array}$ & - \\
\hline $\begin{array}{l}\text { INTERPRET } \\
\text { RESULTS }\end{array}$ & M.9.5.1.1. (M.6.4.2.1.M.6.4.2.2.) & - & - \\
\hline
\end{tabular}


Table 6. Distribution of statistics learning outcomes in Singapore (see https://www.moe.gov.sg/)

\begin{tabular}{|c|c|c|c|}
\hline $\begin{array}{l}\text { STATISTICAL PROCESS } \\
\text { COMPONENT }\end{array}$ & LEVEL A & LEVEL B & LEVEL C \\
\hline $\begin{array}{l}\text { FORMULATE } \\
\text { QUESTION }\end{array}$ & - & $\mathrm{P} 2.1$. & - \\
\hline $\begin{array}{l}\text { COLLECT } \\
\text { DATA }\end{array}$ & P1.1. P3.1. SO1.2. P4.2. & (P2.1.) & $* \mathrm{H} 2.1$ \\
\hline $\begin{array}{c}\text { ANALYZE } \\
\text { DATA }\end{array}$ & $\begin{array}{c}\text { P1.2 P1.3. P2.2. P3.2.P3.3. } \\
\text { P5.1. } \\
\text { P6.3. SO1.1. H1.3. (P1.1., } \\
\text { P3.1., SO1.2. P4.2.) }\end{array}$ & 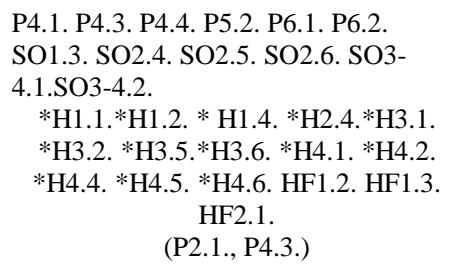 & $\begin{array}{c}{ }^{*} \mathrm{H} 2.2 .{ }^{*} \mathrm{H} 2.3 .{ }^{*} \mathrm{H} 2.5 \\
* \mathrm{H} 3.3 . \\
\text { *H4. } \\
\text { H4. H4.7. HF1.1. HF1.4. } \\
\text { HF1.5. HF1.6. }\end{array}$ \\
\hline $\begin{array}{l}\text { INTERPRET } \\
\text { RESULTS }\end{array}$ & P6.4. SO1.4. & HF2.2. & - \\
\hline
\end{tabular}

Table 7. Distribution of statistics learning outcomes in USA (see http://www.corestandards.org/Math/Content/)

\begin{tabular}{|c|c|c|c|}
\hline $\begin{array}{l}\text { STATISTICAL PROCESS } \\
\text { COMPONENT }\end{array}$ & LEVEL A & LEVEL B & LEVEL C \\
\hline $\begin{array}{l}\text { FORMULATE } \\
\text { QUESTION }\end{array}$ & 6.SP.A.1. (1.MD.C.4) & - & - \\
\hline COLLECT & & HSS.IC.B.5. & 7.SP.A.2.HSS.IC.B.4. \\
\hline \multicolumn{4}{|l|}{ DATA } \\
\hline $\begin{array}{l}\text { ANALYZE } \\
\text { DATA }\end{array}$ & $\begin{array}{l}\text { 1.MD.C.4. 6.SP.A.2. 6.SP.B.4. } \\
\text { 6.SP.B.5 7.SP.B.3 HSS.ID.A.1. }\end{array}$ & $\begin{array}{l}\text { 2.MD.D.9. 3.MD.B.3. 4.MD. B.4 } \\
\text { 7.SP.B.4 8.SP.A.1. 8.SP.A.2. 8.SP.A.3 } \\
\text { 8.SP.A.4 HSS.ID.A.2 HSS.ID.B.6 } \\
\text { HSS.ID.C.9. HSS.IC.B.3 (HSS.IC.B.5) }\end{array}$ & $\begin{array}{l}\text { 7.SP.A.1 HSS.ID.A.4. } \\
\text { (7.SP.A.2, HSS.IC.B.4) } \\
\text { HSS.IC.A.1. }\end{array}$ \\
\hline $\begin{array}{l}\text { INTERPRET } \\
\text { RESULTS }\end{array}$ & $\begin{array}{c}\text { 6.SP.A.3. HSS.IC.A.2 } \\
\text { HSS.IC.B.6. (1.MD.C. } 4 . \\
\text { 7.SP.B.3) }\end{array}$ & $\begin{array}{l}\text { HSS.ID.A.3 HSS.ID.B.5. HSS.ID.C.7 } \\
\text { HSS.ID.C.8 (2.MD.D.9. 3.MD.B.3. } \\
\text { 4.MD. B.4. 5.MD.B.2. 8.SP.A.2.) }\end{array}$ & - \\
\hline
\end{tabular}

Table 8. Distribution of statistics learning outcomes in New Zealand (see https://nz.ixl.com/standards/maths)

\begin{tabular}{|c|c|c|c|}
\hline $\begin{array}{l}\text { STATISTICAL PROCESS } \\
\text { COMPONENT }\end{array}$ & LEVEL A & LEVEL B & LEVEL C \\
\hline $\begin{array}{l}\text { FORMULATE } \\
\text { QUESTION }\end{array}$ & $\begin{array}{lll}1.3 .1 & 3.3 .1 & 4.3 .1\end{array}$ & $\begin{array}{l}2.3 .1-5.3 .1-6.3 .1 \\
\quad 7.3 .1-8.3 .1\end{array}$ & L7.2.1.1 -L8.2.1.1. \\
\hline $\begin{array}{l}\text { COLLECT } \\
\text { DATA }\end{array}$ & $\begin{array}{l}\text { 2-Q.1 3.3.1.1 4.3.1.1 } \\
5.3 .1 .1\end{array}$ & $\begin{array}{l}\text { 6.3.1.1- 6.3.1.3- 7.3.1.1 } \\
\text { 8.3.1.1- L5.3.1.1 -L5.3.1.1. } \\
\text { L5.3.1.1.c- L7.2.1.1.b }\end{array}$ & $\begin{array}{l}\text { L5.3.1.1.b L5.3.2.1 (8-Z.5- } \\
\text { 8.3.1.3, 9-CC.6) } \\
\text { L6.3.1.1.b L7.2.1.1.a L8.2.1.1. } \\
(13-\text { R.15) }\end{array}$ \\
\hline $\begin{array}{l}\text { ANALYZE } \\
\text { DATA }\end{array}$ & $\begin{array}{l}1.3 .1(2-Q .2-2.3 .1) \text { 2-Q.3-2.3.1) } \\
\text { 3.3.1.2 (3-R.4) (3-R.7) 4-K.2- } \\
\text { 4.3.1.1-4.3.1.2 (4-K.4) (4-K.6) (4- } \\
\text { K.8) (5-H.3-5.3.1.1) (5-H.5-5.3.1.1) } \\
\text { (5-H.7-5.3.1.1) 5.3.1.2 (6-Q.2- } \\
6.3 .1 .1) 6-Q .3-6.3 .1 .1)(6-Q .10- \\
6.3 .1 .1)(6-Q .11-6.3 .1 .1)\end{array}$ & $\begin{array}{c}\text { (2-Q.4-2.3.1) (3-R.2-3.3.1.1) } \\
(3-R .9-3.3 .1 .1)(5-H .11-5.3 .1 .1) 6.3 .1 .2 \\
(6-Q .15) 6.3 .1 .3(7-E E .16-7.3 .1 .1) \\
\text { (7-EE.17-7.3.1.1) 7.3.1.2 (7-EE.18-7.3.1.2) } \\
\text { 7.3.1.3 -8.3.1.2 -8.3.1.3- L5.3.1.1.d } \\
\text { L5.3.1.1.e 8-Z.2, 9-CC.2, 10-BB.2) } \\
(10-B B .4,11-N N .2,12-C C .2,9-C C .5) \\
\text { L6.3.1.1.a- L6.3.1.1.c- L6.3.1.1.e } \\
\text { L8.2.1.1.c-L8.2.1.1.d }\end{array}$ & $\begin{array}{l}(10-B B .5,11-N N .3,12-C C .3) \\
(13-R .8) \text { L7.2.1.1.c 13-R.4) }\end{array}$ \\
\hline $\begin{array}{l}\text { INTERPRET } \\
\text { RESULTS }\end{array}$ & L5.3.1.1.f & $\begin{array}{c}\text { 7.3.1.3- L6.3.2.1- L7.2.1.2.a } \\
\text { L7.2.2.1-. L7.2.2.1.b -L8.2.1.1.C }\end{array}$ & $\begin{array}{l}\text { L6.3.1.1.d -L7.2.1.1.C } \\
\text { L7.2.1.2.b -L7.2.1.2.c } \\
\text { L8.2.1.1.b- L8.2.1.2.a }\end{array}$ \\
\hline
\end{tabular}


Table 9. Distribution of statistics learning outcomes in Korea (see http://ncic.re.kr/)

\begin{tabular}{|c|c|c|c|}
\hline $\begin{array}{l}\text { STATISTICAL PROCESS } \\
\text { COMPONENT }\end{array}$ & LEVEL A & LEVEL B & LEVEL C \\
\hline $\begin{array}{l}\text { FORMULATE } \\
\text { QUESTION }\end{array}$ & - & İ.5.3 & - \\
\hline $\begin{array}{l}\text { COLLECT } \\
\text { DATA }\end{array}$ & İ.1. İ.4.1. İ.3.1. & & - \\
\hline $\begin{array}{l}\text { ANALYZE } \\
\text { DATA }\end{array}$ & $\begin{array}{l}\text { İ.2.1 İ.3.2 İ.5.1. İ.5.2. L.9.1. L.9.4. } \\
\text { (İ.4.1. İ.3.1.) }\end{array}$ & $\begin{array}{c}\text { I.2.2. İ.4.2. I..4.3. O.6.1. O.6.2. } \\
\text { O.7.1. 0.7.2. O.7.3. O.7.4. L.9.3. } \\
\text { (I.5.3.) }\end{array}$ & L.9.5. \\
\hline $\begin{array}{l}\text { INTERPRET } \\
\text { RESULTS }\end{array}$ & - & - & - \\
\hline
\end{tabular}

\section{APPENDIX 2}

Table 10. Statistics subjects and the distribution of the class levels of these subjects in terms of countries

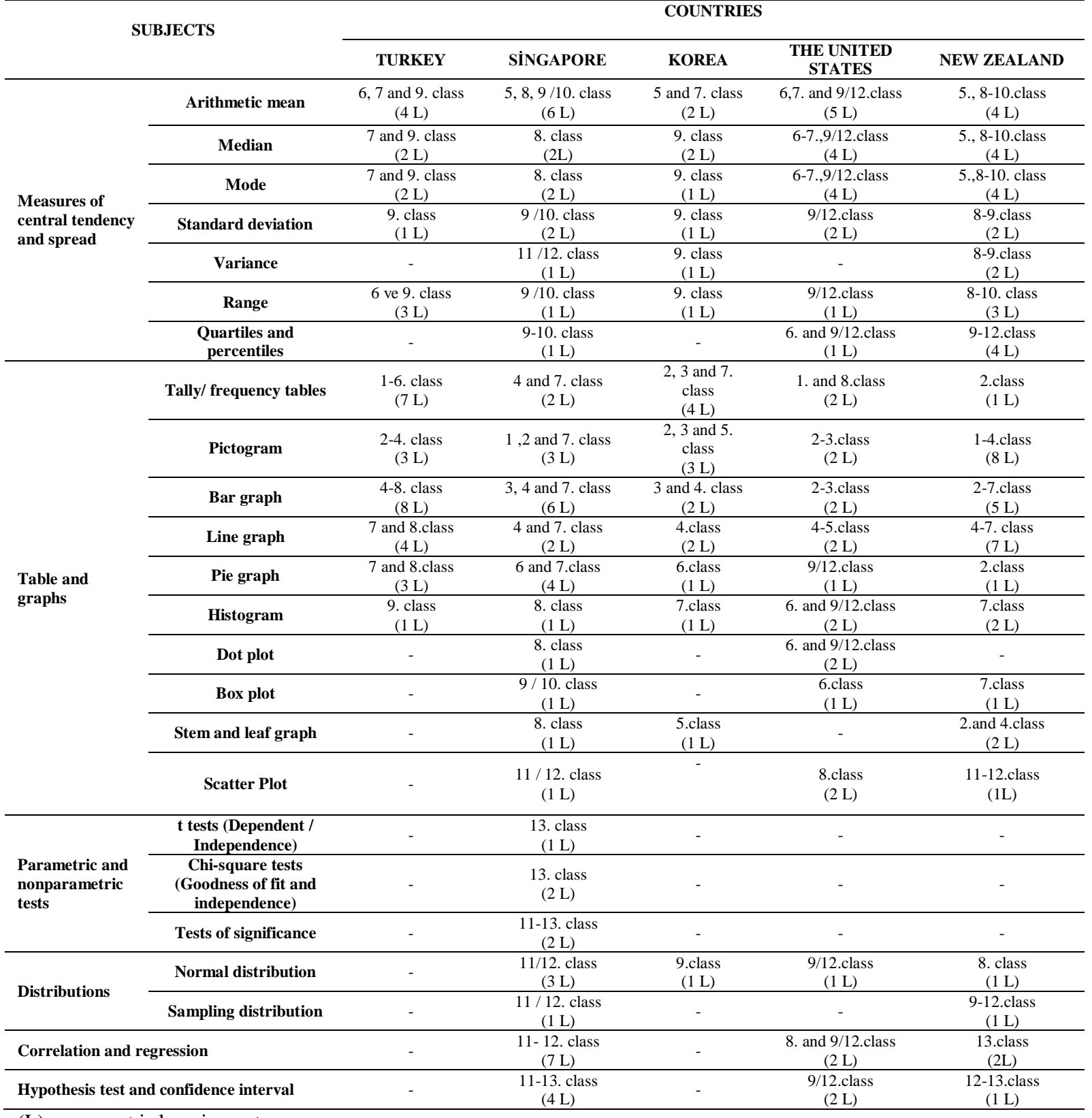

(L): represent is learning outcome

As examining Table 10, concepts regarding measures of central tendency and spread and table and graphs are included in the countries, yet Turkey is detected to be at more inadequate level on the aspect of concepts 
given at both categories in comparison of other countries. Particularly, learning outcomes that meet variance, quartiles and percentiles as measures of spread and dot, box plots, stem and leaf graph, scatter plot in table and graphs are not seen in Turkey. However, learning outcomes reflecting these concepts are seen in other countries. For example; in the process lasting from primary school to high school, learning outcomes reflecting Level A, B and $\mathrm{C}$ based on forming and interpreting table and graphs are included; for Singapore and USA regarding dot plot, for Singapore, USA, and New Zealand regarding box plot and scatter plot and for Singapore, USA, Korea and New Zealand regarding stem and leaf graphs. These kinds of graphs that are included in the least two of the countries are not found in Turkey and pictogram, bar, line, pie and histogram graphs are commonly used for presenting data visually. Tally and frequency tables are often applied for representation of data in comparison of other countries. As in the table, mean for measures of central tendency and spread and bar graph for table and graphs according to other subjects and concepts are more commonly used. Besides, grade levels including these concepts are shown to be varied. As concepts of median and mode are started to be given in secondary grades in other countries, these concepts are started to be given from $9^{\text {th }}$ grade in Korea. Similarly, concept of histogram is started to be given in secondary school in other countries as this concept is among learning outcomes at the level of high school in Turkey. As subjects and concepts regarding inferential statistics such as parametric and nonparametric tests, distributions, correlation and regression, hypothesis test and confidence interval are put more emphasis in Singapore, only normal distribution from these concepts are addressed in Korea, these concepts are shown to be limited on aspect of number of learning outcomes and content of the subject in New Zealand and USA Inferential statistics which is touched as only one subject or with limited learning outcomes in most of the countries is not included in any way in Turkey. In other words, providing subjects and concepts of inferential statistics to students is not included in objectional behaviour of mathematics curriculum in Turkey. Besides, when taking mathematics curriculum depending on grade levels through the countries into consideration, concepts such as frequency table, pictogram and bar graph, mean, mode and median are touched on in low levels and they are switched towards the concepts of standard deviation, line and pie graph, histogram, parametric and nonparametric tests, distributions, correlation and regression, hypothesis test and confidence interval in higher levels. In this sense, principle of simple to complex applied in mathematics curriculum in all countries is seen to be common, yet addressing level of the subjects depending on grade levels for every country can be varied. 


\section{Farklı Ülkelerin Matematik Öğretim Programlarının İstatistik Öğrenme Alanı Açısından Karşılaştırılması}

\section{Giriş}

Verilerin hâkim olduğu yaşamımızda, veriler üzerinden etkili karar alabilme ve çıarımda bulunmaya olan ihtiyaç, bireylerin istatistiğe yönelik bilgi ve becerilere sahip olmalarını ve bu bilgilerini yaşama aktarabilmelerini bir zorunluluk haline getirmektedir. Nitekim istatistiğe yönelik bu tür becerilere sahip bireyler, karşılaştıkları verileri anlamlandırarak etkili kararlar alabilmektedir. National Council of Teachers of Mathematics [NTCM] (2000) standartlarında, değişen dünya şartlarına ayak uydurmada istatistiksel bilgilere gereken önemin verilmesine dikkat çekilmekte ve istatistiğin matematik eğitiminin temel taşlarından birisini oluşturduğu belirtilmektedir. Ayrıca istatistik eğitiminin nihai amac1; istatistik okuryazarı ve istatistik bilgisini yaşamına aktarabilen bireyler yetiştirilmesi olarak gösterilmektedir (Franklin vd.,, 2007). Bu amaca paralel olarak tüm eğitim kademelerinde istatistik öğretimine yönelik iyileştirmeler yapılması kaçınılmaz olmaktadır (Cooper, 2002). Bu doğrultuda, birçok ülkenin ilkokuldan üniversiteye kadar tüm eğitim kademelerinde istatistik konularına daha geniş çapta yer verilmekte ve istatistik öğretimini geliştirici düzenlemelere rastlanmaktadır (Ben-Zvi, \& Garfield, 2008). Bu yönelimin ülkemizde de etkisini gösterdiği ve Milli Eğitim Bakanlığı [MEB] (2005) tarafindan yapılan düzenleme ile 2005 yılından itibaren matematik öğretim programlarında istatistik öğrenme alanına ilişkin konu ve kazanımlara yer verildiği görülmektedir. Yapılan düzenlemelerin öğrencilerin iyi bir istatistik okuryazarı olarak yetişmesinde dünya genelinde istatistik eğitimine yönelik eğilimlere paralel olmasının önemli olduğu düşünülmektedir. Bu durum ise şüphesiz ülkelerin matematik öğretim programlarında istatistik öğrenme alanına verdikleri ağıllık ve istatistik eğitiminin önemli çıktıları olarak tanımlanan istatistik okuryazarlığ 1 , istatistiksel düşünme ve istatistiksel muhakeme yeterliklerine yönelik uygulamalarda farklılaşmalara sebep olmaktadır. Bu doğrultuda, farklı ülkelerin matematik öğretim programlarındaki istatistik öğrenme alanının incelenmesi ve ülkemizde yürürlükte olan matematik öğretim programının diğer ülkelerle karşılaştırılması ihtiyacı ortaya çıkmaktadır. Bu çalışmada Türkiye ile Singapur, Kore, Amerika ve Yeni Zelanda'nın matematik öğretim programlarının istatistik öğrenme alanı açısından karşıllaştırılması amaçlanmıştır. $\mathrm{Bu}$ amaç doğrultusunda, istatistik öğrenme alanında yer alan kazanımlar üzerinden bir karşılaş̧ırma yapılmıştır. Ülkemizde "kazanım" olarak adlandırılan öğrenme hedefleri, Singapur ve Kore'de "içerik", Amerika'da "standart" ve Yeni Zelenda'da "amaç" olarak belirtilmiştir. Çalışmaya dahil edilen ülkelerin öğretim programlarında yer alan bu ifade farklılıklarının karışıklığa yol açmaması için mevcut çalışmada bu hedefler için "kazanım" ifadesi kullanılmıştır.

\subsection{Teorik Cerçeve}

$\mathrm{Bu}$ çalı̧̧mada ülkelerin matematik öğretim programlarının istatistik öğrenme alanı açısından karşılaştırılmasında, istatistik öğretimine yönelik belirlediği ilkeler ile dikkat çeken GAISE (Franklin vd., 2007) raporunda yer alan kuramsal çerçeve kullanılmıştır. GAISE raporunda, istatistik öğretimi için istatistiksel süreç temel alınmakta ve okullarda yapılan öğretimde istatistiksel süreç aşamalarını ön plana çıkaran uygulamalar hedeflenmektedir. Ayrıca raporda istatistiksel süreç ile ilgili sunulan çerçevede istatistiksel süreç aşamalarına ilişkin göstergeler üç hiyerarşik seviyede (A, B ve C) ele alınmıştır. Bu çalışmaya dahil edilen ülkelerin matematik öğretim programları istatistik öğrenme alanı açısından incelenirken istatistiksel süreç aşamaları ve bu aşamalara ilişkin üç farklı seviyede tanımlanan göstergeler temel alınmıştır.

\subsubsection{Istatistiksel Süreç}

İstatistik, bireylerin yaşamına yön vermesine ve aldıkları kararların niteliği hakkında farklı düşünme türlerini hayata geçirmesine olanak sunmaktadır. İstatistiğin bu öneminden hareketle okullarda istatistik öğretimlerinin etkili olarak yapılması önemli bir ihtiyaç olarak karşımıza çıkmaktadır. GAISE raporunda, istatistik öğretiminin niteliğinin arttırılmasında öğrencinin öğrenme ortamındaki etkinliğinin önemli bir değişken olduğunun altı çizilmektedir (Franklin vd., 2007). Öyle ki, istatistiksel süreç aşamalarını deneyim etme imkanı bulan öğrencilerin istatistiksel anlamda aktif ve üretken olacağı vurgulanmaktadır (NTCM, 2000). Dolayısıyla GAISE raporu, istatistik öğretiminin daha etkili olmasında istatistiksel sürece anahtar bir rol yüklemektedir. Nitekim Rumsey (2002) istatistik eğitimine yönelik belirttiği hedefler arasında istatistiksel süreci yönetebilen bireyler yetiştirilmesine dikkat çekmektedir. Birçok çalı̧̧mada da istatistiksel sürecin önemine işaret edilmektedir (Güven, Öztürk, \& Özmen, 2015; Newton, Dietiker, \& Horvath, 2011; Özmen, 2015; Rumsey, 2002; Topan, 2019; Watson, 2006). Bu anlamda öğrencilerin istatistiksel bilgi ve becerilerinin geliştirilmesinde problemi belirleme, veri toplama, veri analizi ve sonuçların yorumlamasını içeren araştırma döngüsünün önemli olduğu açıkça görülmektedir (Franklin vd., 2007; Özmen, 2015; Özmen, \& Baki, 2017). Bu aşamalar bireylerin araştırma deneyimi elde etmeleri, eleştirel yaklaşım sergilemeleri ve psikomotor gelişimlerine katkıda bulunmaktadır (Wild, \& Pfannkuch, 1999). Dolayısıyla istatistiksel süreç, etkili bir istatistik öğretiminin önemli faktörlerinden biri olarak karşımıza çıkmaktadır (Franklin vd., 2007). İstatistik öğretiminde bu tür bir sürecin temel alınması etkili öğrenme çıktılarının oluşması açısından eğitimcilere de katkı sağlayacaktır (Groth, 2013). 
Bunun yanı sıra, istatistik öğretimlerinin istatistiksel süreç aşamalarına göre planlanması ve bu doğrultuda etkinliklerin yapılandırılmasının öğrenme ortamlarının zenginleşmesi ve öğrencilerin daha aktif katılımının sağlanmasında önemli bir katkı sunacağı düşünülmektedir. Ayrıca istatistiksel sürece göre tasarlanan öğretimin, öğrencilerin araştırmacı kimliği kazanarak yetiştirilmesine de firsat sunacağı ve bu anlamda öğretimsel açıdan daha etkili sonuçlar sağlayacağı öngörülmektedir. İstatistiksel sürecin bu işlevsel rolü, öğretim programlarının istatistik öğrenme alanı açısından karşılaştırılması fikrinin ortaya çıkmasında etkili olmuştur. Bu anlamda, ülkelerin matematik öğretim programlarındaki istatistik öğrenme alanı istatistiksel süreç açısından karşılaştırılmıştır. Bu karşılaştırmada istatistiksel sürecin aşamalarına yönelik farklı seviyelerde beklenen davranışların açıklanması ve istatistik öğretimi için temel alınacak tavsiyelere yer verilmesi nedeniyle GAISE (Franklin vd., 2007) raporu temel alınmıştır.

\subsubsection{GAISE Raporu}

American Statistical Association (ASA) tarafından yayınlanan GAISE, istatistik eğitimine yönelik sunulan tavsiyelerin ve öğretimsel ilkelerin yer aldığı rapordur. Bu raporun beyan ettiği ilkeler tüm dünyayı etkilerken, istatistik öğretimine yönelik geniş bir çerçeve sunması açısından da önem taşımaktadır. GAISE raporunda, istatistik okuryazarı öğrencilerin yetiştirilmesi istatistik öğretiminin temel amacı olarak ele alınmakta ve bu doğrultuda öğretimsel öneriler yer verilmektedir. Bu raporda istatistik öğretiminde nihai hedef olarak istatistik okuryazarlığına odaklanılmış ve her lise mezunu bireyin mutlu ve üretken bir hayat sürmesinde istatistiksel muhakeme becerisine sahip olması ve bu beceriyi günlük hayata yansıtabilmesinin gerekliliği vurgulanmıştır (Franklin vd., 2007). Ayrıca toplum adına bilinçli ve üretken bireyler yetiştirmenin ancak iyi bir istatistik eğitimi sonucu mümkün olacağına işaret edilmiştir. Bu anlamıyla GAISE raporları istatistik öğretiminin nasıl yapılacağı noktasında öğretmenlere önemli ipuçları sunmaktadır. Dünyada istatistik eğitimine yönelik önemli bir kaynak olarak gösterilen bu raporlara, öğrenme ortamlarının tasarlanmasında da sıklıkla başvurulmaktadır. Bunun temelinde, istatistik öğretiminde öğrencileri aktif kılacak ve istatistik kavramlarının onlar için daha anlaşılır hale getirilmesini sağlayacak istatistiksel süreç yer almaktadır. İstatistiksel süreç zengin bir istatistik öğretiminin haritası olarak nitelendirilmektedir (Franklin vd., 2007). Bu doğrultuda, GAISE raporunda istatistiksel süreç birbirini izleyen 4 aşamadan oluşmaktadır. $\mathrm{Bu}$ aşamalardan ilki problem durumunun belirlenmesi olup istatistiksel süreci başlatması ve sonraki aşamaların gelişimine yön vermesi bakımından önemli görülmektedir. $\mathrm{Bu}$ kısımda hedef alınan konuyu yansıtacak uygun bir problemin oluşturulması ve elde edilecek verinin türüne karar verilmesi önemsenmektedir. İkincisi, araştırma problemine uygun verilerin toplanmasıdır. Bu kısımda ulaşılması istenen evreni temsil edecek örneklemin seçimi, büyüklüğü, veri toplama yöntemleri üzerinde durulmakta ve yapılacak analiz için uygun ölçümlere karar verilmektedir. Üçüncüsü verilerin analizi olup bu kısımda toplanan veriler sayısal olarak özetlenebileceği gibi tablo ve grafiksel temsillerle görsel olarak da sunulabilmektedir. Son aşama ise elde edilen sonuçların yorumlanarak uygun çıkarımların yapıldığı aşamadır. $\mathrm{Bu}$ kapsamda elde edilen sonuçlar ait olduğu bağlamda ele alınarak yorumlanmaktadır. Bu esnada farklı bireylerin katılımı söz konusu olabileceği için yeni problem durumlarının oluşacağı düşünülmekte ve böylece istatistiksel sürecin bir süreklilik arz edeceği varsayılmaktadır. Bu aşamaların ilişkilendirilerek anlamlandırılması zamana ve öğretim uygulamalarına bağlı olarak gerçekleşmektedir. Bu gelişimsel süreç GAISE raporunda, her bir aşama için betimsel istatistikten çıkarımsal istatistiğe uzanacak şekilde üç seviyede (A, B ve C seviyeleri) sunulmaktadır. Başka bir ifade ile GAISE raporunda istatistiksel süreç temel becerilerden yola çıarak daha üst düzey becerileri kazanmaya yönelik bir çerçeve olarak yer almaktadır. Bu doğrultuda A seviyesinde, istatistiğin temel prensiplerini ve istatistiksel kavramların anlamını bilmek ön plana çıkarken; B seviyesinde istatistiğin temel kavramlarının birbirleriyle ilişkilendirilmesi ve istatistiksel durumlar üzerinden karşılaştırmaların yapılması istenmektedir. Son olarak C seviyesi elde edilen sonuçların genellenmesini, ileri düzeyde istatistik kavramlarının bilinmesini ve ilişkilendirilmesini gerektirmektedir (Franklin vd., 2007). Örnek olarak istatistiksel süreç aşamalarından veri toplamaya yönelik, okulda düzenlenecek yılsonu konserine getirilecek müzik grubu belirlenirken A seviyesindeki öğrenciler kendi sınıflarındaki arkadaşlarının görüşlerini alarak basit deneysel bir işlemle veri toplarlar. B seviyesinde, sadece bir sınıftan toplanan verilerin tüm okulu temsil etmeyeceğinin farkına varılarak diğer sınıflar da örnekleme dâhil edilir. Örneklemin evreni temsil edici nitelikte olması gerektiğinin farkına varan öğrenciler, herkesin seçilme olasılığının eşit olduğunu varsayarak rastgele seçimler yapmaya başladıklarında $C$ seviyesine geçmiş olurlar. Böylece, ilk seviyede bir grupla sınırlı olan seçimlerin ikinci seviyede temsilî özellik taşıması ve son olarak da büyük bir topluluktan rastgele seçimler yapılmasına doğru bir gelişim görülmektedir.

GAISE raporunun istatistik öğretiminin niteliğini arttırıcı önerileri ve uygulamaları, istatistik öğretiminin derecesinin belirlenmesinde önemli bir yere sahiptir. Bu öneri ve uygulamalar doğrultusunda gerçekleştirilen istatistik öğretiminin etkili olacağı belirtilmektedir (Franklin vd., 2007). Bu noktada öğrenme ortamlarının tasarlanmasında temel oluşturan matematik öğretim programında yer alan istatistik öğrenme alanına ilişkin hedef ve kazanımlar ön plana çıkmaktadır. Öyle ki, bu kazanımların yapılacak olan istatistik öğretimine yönelik fikir vereceği düşünülmektedir. Dolayısıyla, bu raporun sunduğu kuramsal yapının temel alınması, daha etkili istatistik öğretimleri için öğretim programlarının kaynak oluşturup oluşturmadığını görebilme açısından önemli 
olmaktadır. Bu bilgilerden hareketle, GAISE (Franklin vd., 2007) raporunda istatistiksel süreç aşamaları ve her bir aşamanın üç gelişimsel seviye kapsamındaki göstergelerine ilişkin sunulan iki boyutlu kuramsal yapı Tablo 1 'de verilmiştir.

Tablo 1. GAISE (Franklin vd., 2007, s.14) raporu kuramsal çerçevesi

\begin{tabular}{|c|c|c|}
\hline İSTATISTIIKSEL & A SEYIYYSSI & B SEYIYYFSi \\
\hline
\end{tabular}

ASAMALARI

B SEVIYESİ

\begin{tabular}{|c|c|c|c|}
\hline $\begin{array}{l}\text { PROBLEM } \\
\text { DURUMUNU } \\
\text { BELIIRLEME }\end{array}$ & $\begin{array}{c}\text { Hangi sorunun istatistiksel } \\
\text { soru olacağına dair } \\
\text { farkındalığın başlaması } \\
\text { Öğretmen ilgili soruyu sorar. } \\
\text { Sorular sinıfla sınılıdır. }\end{array}$ & $\begin{array}{l}\text { Hangi sorunun istatistiksel soru } \\
\text { olacağına dair artmış bir } \\
\text { farkındalık } \\
\text { Öğrenciler kendi ilgilerine göre } \\
\text { soruları sormaya başlarlar. } \\
\text { Sorular sınıfla sınırlı değildir. }\end{array}$ & $\begin{array}{c}\text { Öğrenciler hangi sorunun } \\
\text { istatistiksel soru olacağına dair } \\
\text { ayrımı yapabilir } \\
\text { Öğrenciler kendi ilgilerine göre } \\
\text { soruları sorarlar. } \\
\text { Genelleştirilebilir sorular araştırılır. }\end{array}$ \\
\hline $\begin{array}{c}\text { VERİ } \\
\text { TOPLAMA }\end{array}$ & $\begin{array}{l}\text { Farklılıklar için henüz tasarım } \\
\text { bulunmamaktadır. } \\
\text { Sinıfla iş birliği } \\
\text { Basit deney }\end{array}$ & $\begin{array}{l}\text { Farklı1ıklar için tasarıma yönelik } \\
\text { farkındalık başlar. } \\
\text { Örnek anketler; rastgele seçimi } \\
\text { kullanılmaya başlanır. } \\
\text { Karşılaştırmalı deney; rastgele } \\
\text { paylaşımı kullanılmaya başlanır. }\end{array}$ & $\begin{array}{c}\text { Farklılıklar için öğrenciler tasarım } \\
\text { yaparlar. } \\
\text { Rastgele seçimlerle örnekleme } \\
\text { tasarımları } \\
\text { Rastgelelik kavramının kullanıldığı } \\
\text { deneysel tasarımlar }\end{array}$ \\
\hline
\end{tabular}

\begin{tabular}{|c|c|c|c|}
\hline $\begin{array}{c}\text { VERİ } \\
\text { ANALİZi }\end{array}$ & $\begin{array}{c}\text { Belli örneklerle ilgili } \\
\text { bağlamlarda dağılımların belli } \\
\text { özelliklerini kullanmak } \\
\text { Grup içerisindeki değişkenliği } \\
\text { göstermek } \\
\text { Kişiden kişiye karşılaştırma } \\
\text { Kişiden gruba karşılaştırma } \\
\text { Gruptan gruba farkındalık } \\
\text { başlar. } \\
\text { İki değişken arasındaki ilişkiyi } \\
\text { gözlemlemek }\end{array}$ & $\begin{array}{c}\text { Analiz için araçlar olarak } \\
\text { dağılımlarla ilgili belli özelliklerin } \\
\text { kullanılmayı öğrenilir. } \\
\text { Grup içerisindeki değişkenliğin } \\
\text { ölçümü } \\
\text { Temsillerde gruptan gruba } \\
\text { karşılaştırmak } \\
\text { Örnekleme hatasını kabul etmek } \\
\text { Bazı ilişki ölçümleri; ilişkiyle ilgili } \\
\text { basit modeller }\end{array}$ & $\begin{array}{c}\text { Analizde genel bir kavram olarak } \\
\text { dağılımları anlamak ve kullanmak } \\
\text { Grup içerisinde değişkenliği ölçmek; } \\
\text { gruplar arasındaki değişkenliği ölçmek } \\
\text { Temsillerin kullanımı ve değişkenliğin } \\
\text { ölçümü ile gruplar arası karşılaştırma } \\
\text { Örnekleme hatasını tanımlamak ve } \\
\text { ölçmek } \\
\text { İlişkinin ölçümü; ilişkiye uygun } \\
\text { modeller }\end{array}$ \\
\hline $\begin{array}{l}\text { SONUÇLARI } \\
\text { YORUMLAMA }\end{array}$ & $\begin{array}{c}\text { Öğrenciler verinin ötesine } \\
\text { bakamıyorlar. } \\
\text { Sınıfın ötesine genelleştirme } \\
\text { yoktur. } \\
\text { Farklı durumlarda iki kişi } \\
\text { arasındaki farklılıkları fark } \\
\text { etmek } \\
\text { Temsillerdeki ilişkiyi } \\
\text { gözlemlemek }\end{array}$ & $\begin{array}{c}\text { Öğrenciler verinin ötesine bakmanın } \\
\text { kullanışlı olduğunu kabul ederler. } \\
\text { Örneklemin popülasyonu temsil } \\
\text { edip etmeyeceğini kabul ederler. } \\
\text { Farklı durumlarda iki grup } \\
\text { arasındaki farklılıkları fark ederler. } \\
\text { Gözlem ve deney arasındaki ayrımla } \\
\text { ilgili farkındalık } \\
\text { İlişkinin gücündeki farklılıkları fark } \\
\text { etmek } \\
\text { İlişkiyle ilgili modellerle ilgili temel } \\
\text { yorumlar } \\
\text { İlişki ve sebep-sonuç arasındaki } \\
\text { ayrımın farkında olmak }\end{array}$ & $\begin{array}{c}\text { Öğrenciler bazı bağlamlarda verinin } \\
\text { ötesine bakabilirler. } \\
\text { Örneklemden popülasyona genelleme } \\
\text { yapmak } \\
\text { Deney sonuçları üzerinde rasgeleliğin } \\
\text { etkisinin farkında olmak } \\
\text { Gözlem ve deney arasındaki } \\
\text { farklılıkları anlamak } \\
\text { İlişkinin gücünü ölçümünü } \\
\text { yorumlamak } \\
\text { İlişkiyle ilgili modelleri yorumlamak } \\
\text { İlişki ve deney sonuçları arasında } \\
\text { ayrım yapmak }\end{array}$ \\
\hline
\end{tabular}

GAISE raporunda bireylerin iyi bir istatistik okuryazarı olması için istatistiksel süreci deneyimlemelerinin önemli olduğu ifade edilmiştir. Bu noktada eğitimci ve program geliştirenlerin, öğrencilerin istatistiksel süreci deneyim etmelerini sağlayacak şekilde uygulamalar tasarlaması gerektiği belirtilmiştir. Bu sayede istatistiğin son yıllarda kazandığı ivme ile GAISE raporlarının nitelikli istatistik öğretimine yönelik vurgulamaları, çoğu ülkenin matematik öğretim programlarında yenilik yapmasına da imkân tanımıştır. Yapılan yenilik çalışmaları kapsamında ülkelerin öğretim programlarında istatistiğe farklı yoğunlukta yer vermiş olması bazı ülkelerin istatistik eğitiminde ön plana çıkmasına zemin hazırlamıştır. Bu nedenle farklı ülkelerin öğretim programlarının karşılaştırmalı olarak incelenmesi, ülkelerin eğitim-öğretim faaliyetleri için üstün ve zayıf yönlerini görmelerine ve etkili görülen uygulamaları kendi sistemlerine entegre etmelerine olanak tanımaktadır. Alan yazın incelendiğinde ise, ülkelerin matematik öğretim programlarının karşıllaştırılmasına yönelik birçok araştırma bulunmaktadır (Altıntaş, \& Görgen, 2014; Çelik, Kul, \& Çalık-Uzun, 2018; Erbilgin, 2014; Erdoğan, Hamurcu, \& Yeşiloğlu, 2016; Güzel, Karataş, \& Çetinkaya, 2010; İncikabı, \& Tuna, 2012; Kaytan, 2007; Kul, \& Aksu, 2016; Özkan, 2006; Özreçberoğlu, \& Kıvanç-Çağanağa, 2016). Bu araştırmalarda, programların genel nitelik ve hedefleri belirtilerek büyük oranda tüm öğrenme alanlarını kapsayacak şekilde matematik öğretim programları karşılaştırılmıştır. Bununla birlikte, ülkelerin matematik öğretim programlarının belirli öğrenme alanları açısından karşılaştırılmasına yönelik araştırmalar da mevcuttur (Arık, 2007; Tezcan, 2016; Uğur-Arslan, 2015). $\mathrm{Bu}$ araştırmalarda, farklı ülkelerin matematik öğretim programları sayılar, cebir, geometri gibi öğrenme alanlarına yönelik incelenmiş olup doğrudan istatistik öğrenme alanına ilişkin incelemelerin yapılmadığ görülmektedir. Bu durum ise ülkelerin istatistik öğrenme alanına yönelik farklılıklar vebenzerlikler açısından 
karşılaştırılması ihtiyacını ortaya koymaktadır. GAISE raporunun istatistik eğitimi için önemli bir kaynak olması ve bu raporda işaret edilen öğretimsel ilke ve uygulamaların ülkelerin öğretim programlarında nasıl veya ne ölçüde temel alındığı da bu karşılaştırmaların yapılmasında önemli bir rol oynamaktadır. Bu anlamda, GAISE raporu dikkate alınarak şekillenen öğretim programlarının nitelikli bir istatistik öğretiminin çıkış noktası olacağ düşünüldüğünde, ülkelerin öğretim programlarının istatistik öğrenme alanı açısından GAISE raporu doğrultusunda benzerlik ve farklılıklar açısından incelenmesi gerektiği düşünülmektedir. Bu noktada, ülkelerin öğretim programlarının istatistik temelinde karşılaştırılarak ele alınması ve sonuçlara bağlı olarak öğretim programlarında gerekli düzenlemeler yapılması, öğrencilerin istatistiksel olarak donanımlı yetişmeleri yönünde gerekli adımların atılmasına fırsat tanıyacaktır. Bu kapsamda mevcut çalışmada, Türkiye ile Singapur, Kore, Amerika ve Yeni Zelenda'nın matematik öğretim programlarında yer alan istatistik kazanımlarını GAISE (Franklin vd., 2007) raporuna göre analiz etmek ve raporda sunulan kuramsal çerçeveye göre kazanımların eğilimini karşılaştırmak amaçlanmıştır. Bu temel amaca bağlı olarak araştırmada ele alınacak sorular aşağıdaki gibi belirlenmiştir:

$>$ Ülkelerde istatistik öğrenme alanına ilişkin kazanımlar GAISE raporunun sunduğu gelişimsel seviyeler açısından nasıl farklılaşmaktadır?

> Ülkelerde istatistik öğrenme alanına ilişkin kazanımlar GAISE raporunun sunduğu istatistiksel süreç aşamaları ve gelişimsel seviyeleri açısından nasıl farklılaşmaktadır?

\section{Yöntem}

$\mathrm{Bu}$ çalışma karşılaştırmalı bir araştırma olup Türkiye ile Singapur, Kore, Amerika ve Yeni Zelanda matematik öğretim programlarının istatistik öğrenme alanı açısından karşılaştırılmasını amaçlamaktadır. Araştırmada ülkelerin öğretim programlarının sunulmasında nitel araştırma desenlerinden doküman analizi yöntemi kullanılmıştır. Doküman analizi yöntemi, araştırmanın hedefi doğrultusunda yazılı belgelerin incelenmesine olanak sağlaması açısından tercih edilmiştir. Beş ülkenin matematik öğretim programları araştırmanın amacı doğrultusunda ve GAISE raporunda yer alan kuramsal çerçeve kapsamında incelenmiştir.

\subsection{Araştırmaya Dahil Edilen Ülkeler}

Araştırmaya dahil edilen ülkelerin belirlenmesinde iki kriter temel alınmıştır. Birincisi; ülkelerin eğitim sistemlerini izlemek amacıyla değerlendirme sınavı olarak yürütülen Uluslararası Matematik ve Fen Eğilimleri Araştırması (TIMSS) ve okuryazarlık kavramını odağına alarak öğrencilerin okulda öğrendikleri bilgi ve becerileri günlük hayata aktarabilme yeteneğine vurgu yapan Uluslararası Öğrenci Değerlendirme Programı (PISA) sınavlarında ilk sıralarda yer alan ülkeler olmasına dikkat edilmiştir. PISA (2015) ve TIMSS (2015) sınavlarında başarılı olan ülkeler incelenerek bu ülkeler arasından Singapur ve Kore çalışmaya dâhil edilmiştir. İkinci kriter olarak; son dönemde istatistik alanında yaptıkları çalışmalar ile ön plana çıkan ülkelerden Amerika (Lovett, \& Lee, 2018; Newton, Dietiker, \& Horvath, 2011) ve Yeni Zelanda (Burgess, 2007; Forbes, 2014) tercih edilmiştir.

\subsection{Veri Toplanması ve Analizi}

Ülkelerin öğretim programlarındaki istatistik öğrenme alanına ait kazanımlar (içerik, standart, amaç) GAISE raporunda istatistiksel süreç aşamaları için belirtilen seviyeler (A, B ve C) doğrultusunda analiz edilmiştir. Araştırma kapsamında incelenen öğretim programları (güncellenme yılları Türkiye için 2018, Singapur ilköğretim ve ortaöğretim kademesi için 2013 ve H1, H2 ve H2 ileri (H2F: 13. sınıf olarak nitelendirilen) kademesi için 2016, Kore için 2015, Amerika için 2012 ve Yeni Zelanda için 2012) GAISE raporunda belirtilen K-12'ye uygun olarak ilkokul, ortaokul ve lise matematik öğretim programlarını kapsamaktadır. Öğretim programlarındaki kazanımlar ve açıklamaları teorik çerçevede belirtilen istatistiksel süreç aşamalarında A, B ve C seviyelerine yönelik göstergeler bağlamında değerlendirilmiştir. Öğretim programlarında yer alan istatistik kazanımlarının ilişkili olduğu aşama ve seviyelere göre sınıflandırılması yapılırken bir kazanımın birden fazla aşamaya yönelik açıklama içermesi durumunda ilgili kazanıma her iki aşamada da yer verilmiştir. Bu tür kazanımlar dâhil olduğu aşamaların ilkinde açık bir şekilde yazılmış (kazanım numarası ve adı), diğer aşamada ise kazanımın sadece numarası belirtilmiştir. Bununla birlikte, kazanımın birden fazla seviyeye uygun olması durumunda, tekrar niteliğindeki durumların oluşmasını engellemek amacıyla ilgili kazanım çıkabileceği en üst seviyeye yazılmıştır. Analiz süreci bir örnek üzerinden Tablo 2’ de gösterilmiştir. 
Tablo 2. Kazanımların kuramsal çerçeveye göre örnek bir analiz (Singapur örneği)

\begin{tabular}{|c|c|c|c|}
\hline $\begin{array}{l}\text { İSTATİSTIKSEL } \\
\text { SÜREÇ } \\
\text { AŞAMALARI }\end{array}$ & A SEVIYYESİ & B SEVIYYESI & C SEVIYYESi \\
\hline $\begin{array}{c}\text { PROBLEM } \\
\text { DURUMUNU } \\
\text { BELİRLEME }\end{array}$ & & & \\
\hline $\begin{array}{c}\text { VERİ } \\
\text { TOPLAMA }\end{array}$ & $\begin{array}{l}\text { SO1.2. Veri toplamak ve } \\
\text { sınıflandırmak, uygun } \\
\text { istatistiksel temsilleri kullanarak } \\
\text { veriyi sunmak (yazılım } \\
\text { programlarını içeren), veriyi } \\
\text { analiz etmek için işbirlikli } \\
\text { olarak çalışır. }\end{array}$ & & \\
\hline $\begin{array}{c}\text { VERİ } \\
\text { ANALİZi }\end{array}$ & (SO1.2.) & $\begin{array}{l}\text { P4.3. Elektronik tablo programı (Excel } \\
\text { gibi) kullanarak çizgi grafiği oluşturur ve } \\
\text { sütun grafiği ile çizgi grafiği arasında } \\
\text { ilişkiyi kurar, hangi grafiğin (ya da her } \\
\text { ikisinin) kullanılabileceğini açıklar. }\end{array}$ & \\
\hline
\end{tabular}

SONUÇLARI

YORUMLAMA

(P: İlköğretim 1-6 düzeyi, SO: Ortaöğretim düzeyi müfredatı kazanımlarını temsil etmektedir)

Tablo 2 incelendiğinde, Singapur'da ortaöğretim düzeyinde yer alan SO1.2. kazanımı veri toplama ve veri analizi aşamalarına yönelik ifadeler içermektedir. Bu yüzden her iki aşamada bu kazanıma yer verilmiştir. Kazanımın ifadesi temel bilgilerin doğrudan kullanımını gerektirdiğinden her iki aşama için bu kazanım A seviyesinde belirtilen göstergeler ile sınırlı olmaktadır. Bununla birlikte, ilkokul 4. sınıf düzeyinde yer alan P4.3. kazanımı, öğrencilerin belli bir istatistiksel soru karşısında çizgi grafiğinin özelliklerini dikkate alarak temel düzeyde işlemler yapmasını gerektirdiğinden A seviyesine yönelik bir hedef davranışı içermektedir. Kazanımın devamında ise sütun ve çizgi grafikleri arasında ilişki kurulması, iki grafik türü arasında karşılaştırma yaparak istatistiksel bir durum karşısında hangi grafiğin kullanılmasının uygun olacağına karar verilmesi gibi B seviyesini karşılayacak ifadeler yer almaktadır. Bu nedenle bu kazanım B seviyesinde yer alacak şekilde değerlendirilmiştir.

Doküman incelemesi yapılırken Forster'in (1995) önerdiği aşamalar dikkate alınmıştır. İlk etapta doküman olarak kullanılan matematik öğretim programlarına birinci elden ulaşmak için detaylı bir araştırma yapılmıştır. İkinci olarak, ulaşılan öğretim programlarının ait olduğu ülkenin Eğitim Bakanlığının sayfasında yer alması dikkate alınarak özgünlükleri kontrol edilmiştir. Daha sonra, öğretim programlarının anlaşılması için her birinin genel ve matematik öğretimine yönelik amaç ve hedefleri incelenmiştir. Bu doğrultuda programlarda yer alan istatistik kazanımlarının anlaşılması ve çözümlenmesi işlemine geçilmiştir. Dördüncü aşamada, incelenen istatistik kazanımları GAISE raporunda yer alan kuramsal çerçeve doğrultusunda analiz edilmiştir. Ülkelerin istatistik öğrenme alanındaki kazanımlarının incelenmesine ilişkin ortak bir analiz prosedürü takip edilmiştir. İlk olarak GAISE raporunda istatistiksel süreç aşamaları ve her bir aşama için üç seviyede beklenen davranışlar detaylı olarak incelenmiştir. Her bir aşama ve seviyeyi birbirinden ayıran durumlar üzerine konuşularak kapsamları ortaya konulmuştur. Böylece ortak bir analiz sürecine geçiş sağlanmıştır. Analize ilişkin prosedür belirlendikten sonra bir ülkenin matematik öğretim programındaki istatistik kazanımları tüm araştırmacılar tarafından birlikte analiz edilmiştir. Bu analizlerde ilk olarak ilgili kazanımın hangi istatistiksel süreç aşaması ile ilişkili olduğuna karar verilmiştir. Kazanımın ilişkili olduğu aşamaya karar verildikten sonra hangi seviyede yer aldığı belirlenmiştir. Karar verme sürecinde anlaşmazlık olması durumunda GAISE raporu ile ilgili kuramsal çerçeve üzerinde tartışılmış ve ortak bir fikre ulaşıncaya kadar tartışmalara devam edilmiştir. Daha sonra her bir araştırmacı bir ülkenin kazanımlarını belirlenen ortak analiz prosedürü doğrultusunda incelemiştir. Bu incelemelerin güvenirliğini sağlamak adına araştırmacıların tamamının istatistik eğitimi alanında çalışmalar yapıp araştırma alanına yakın olmasına dikkat edilmiştir. İncelemeler tamamlandıktan sonra ülkelerin matematik ögretim programlarındaki istatistik kazanımlarının ilişkili olduğu istatistiksel süreç aşaması ve seviyesi açısından sınıflandırılmasına ilişkin betimsel analize başvurulmuştur. Araştırmacılar, betimsel analiz sonucunda gerçekleştirdikleri kodlama işlemini tamamladıktan bir süre sonra tekrar kodlama yaparak sonuçların gerçeği yansıtıp yansıtmadığını teyit etmişlerdir. Analiz işleminin son aşamasında elde edilen veriler, frekans ve yüzdeler yardımıyla sunulmuştur. Son aşamada ise analiz sonuçları araştırma problemi doğrultusunda yorumlanmıştır. 


\section{Bulgular}

Ülkelerin matematik öğretim programındaki istatistik öğrenme alanı kazanımları GAISE raporunun sunduğu kuramsal çerçeve kullanılarak incelenmiştir. Elde edilen bulgularda ilk olarak ülkelerin istatistik kazanımları kuramsal çerçevenin sunduğu hiyerarşik seviyelere göre değerlendirilmiştir. Sonrasında seviyelerle ilişkilendirilen kazanımların istatistiksel süreç aşamalarına göre dağllımına yer verilmiştir.

Matematik öğretim programlarında yer alan istatistik kazanımlarının ilişkili olduğu seviyelerin (A, B ve C) ülkeler açısından dağılımı Grafik 1' de verilmiştir.

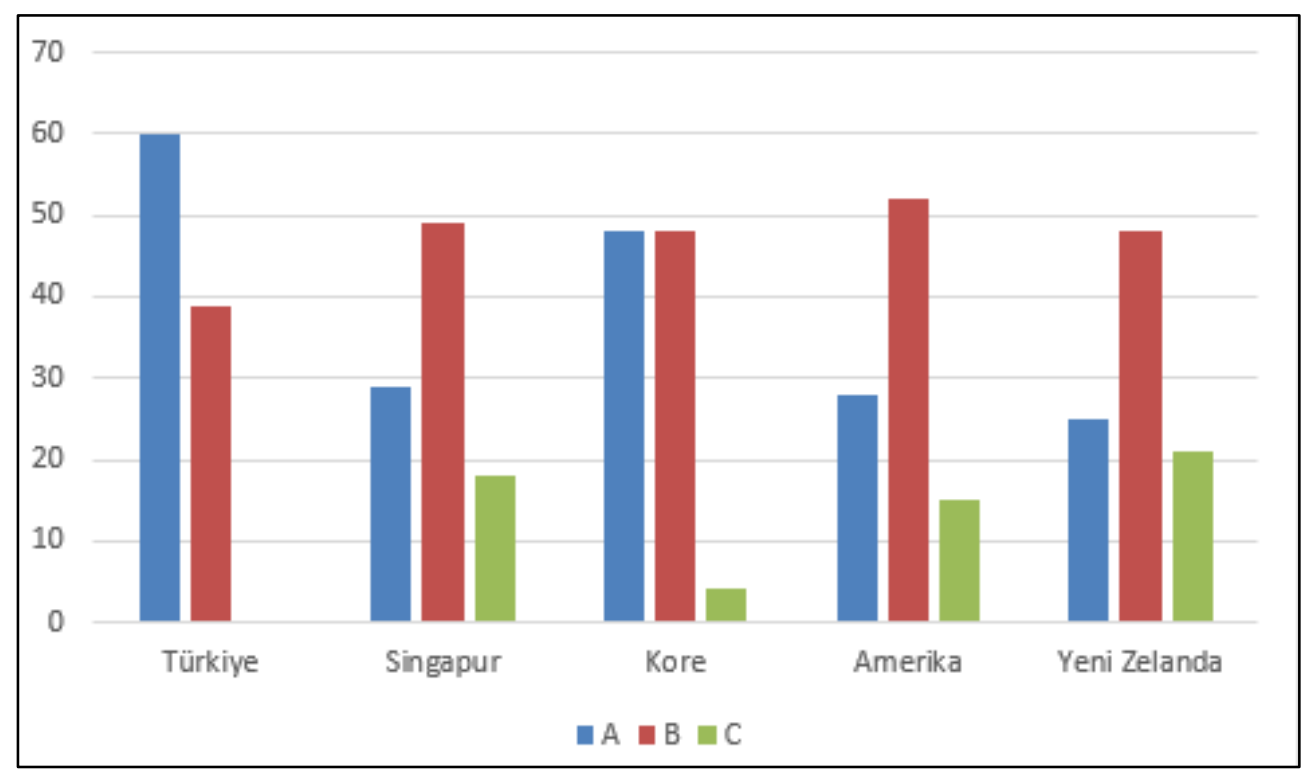

Grafik 1. Ülkelerin istatistik kazanımlarının A, B ve C seviyelerine göre dağılımı (\%)*

*Ülkelerin istatistik öğrenme alanına ilişsin tüm kazanımları dikkate alınarak hesaplamalar yapılmıştır.

Grafik 1 incelendiğinde, istatistiğe yönelik ileri düzeyde bilgi ve beceri gerektiren B ve C seviyesindeki kazanımların Yeni Zelanda ve Singapur'da daha yoğun olarak yer aldığı görülmektedir. Ayrıca Amerika ve Kore'nin matematik öğretim programlarında da bu seviyelerdeki kazanımlara yer verildiği dikkat çekmektedir. Bununla birlikte, Türkiye'deki istatistik öğrenme alanı ile ilgili kazanımların en fazla B seviyesine kadar çıkabildiği ve $\mathrm{C}$ seviyesinde herhangi bir kazanıma yer verilmediği tespit edilmektedir. Ülkemizdeki temel düzeyde istatistik bilgisi gerektiren A seviyesine yönelik kazanımların oranının hem ülkemiz bazında hem de diğer ülkelere göre daha fazla olduğu dikkat çekmektedir. Buna karşın Singapur, Yeni Zelanda ve Amerika'da B seviyesindeki kazanımların oranı daha fazla iken, Kore'de A ve B seviyesindeki oranların eşit ve C seviyesine kıyasla daha fazla olduğu görülmektedir.

Ülkelerin matematik öğretim programlarında istatistik öğrenme alanına verilen ağırlık ve bu alana ait kazanımların ilişkili olduğu istatistiksel süreç aşamalarının A, B ve C seviyelerine uygunluklarına yönelik bulgular (frekans ve yüzde cinsinden) Tablo 3’te yer almaktadır. 
Tablo 3. Ülkelerin istatistiksel süreç aşamalarındaki kazanımlarının A, B ve C seviyeleri açısından dağılımı

\begin{tabular}{|c|c|c|c|c|c|c|c|c|c|c|c|c|c|c|c|c|c|c|c|c|c|}
\hline \multirow{3}{*}{$\begin{array}{c}\text { İSTATİSTIKKSEL } \\
\text { SÜREÇ } \\
\text { AŞAMALARI }\end{array}$} & \multicolumn{20}{|c|}{ ÜLKELER } & \multirow{3}{*}{$\begin{array}{c}\text { Genel } \\
\text { Toplam }\end{array}$} \\
\hline & \multicolumn{3}{|c|}{ TÜRKIYY } & \multirow[t]{2}{*}{ Toplam } & \multicolumn{3}{|c|}{ SINGAPUR } & \multirow[t]{2}{*}{ Toplam } & \multicolumn{3}{|c|}{ KORE } & \multirow[t]{2}{*}{ Toplam } & \multicolumn{3}{|c|}{ AMERÍKA } & \multirow[t]{2}{*}{ Toplam } & \multicolumn{3}{|c|}{ YENİ ZELANDA } & Toplam & \\
\hline & $\mathbf{A}$ & B & C & & $\mathbf{A}$ & B & $\mathrm{C}$ & & $\mathbf{A}$ & B & $\mathrm{C}$ & & $\mathbf{A}$ & B & $\mathrm{C}$ & & $\mathbf{A}$ & B & $\mathrm{C}$ & & \\
\hline $\begin{array}{c}\text { PROBLEM } \\
\text { DURUMUNU } \\
\text { BELIRLEME }\end{array}$ & $\begin{array}{c}* 1 \\
(\% 3)\end{array}$ & $\begin{array}{c}1 \\
(\% 3)\end{array}$ & - & $\begin{array}{c}* * 2 \\
(\% 13)\end{array}$ & - & $\begin{array}{c}1 \\
(\% 1)\end{array}$ & - & $\begin{array}{c}1 \\
(\% 7)\end{array}$ & - & - & - & - & $\begin{array}{c}2 \\
(\% 4)\end{array}$ & - & - & $\begin{array}{c}2 \\
(\% 13)\end{array}$ & $\begin{array}{c}3 \\
(\% 3)\end{array}$ & $\begin{array}{c}5 \\
(\% 5)\end{array}$ & $\begin{array}{c}2 \\
(\% 2)\end{array}$ & $\begin{array}{c}10 \\
(\% 67)\end{array}$ & $\begin{array}{c}* * * 15 \\
(\% 6)\end{array}$ \\
\hline $\begin{array}{c}\text { VERI } \\
\text { TOPLAMA } \\
\end{array}$ & $\begin{array}{c}2 \\
(\% 6) \\
\end{array}$ & $\begin{array}{c}2 \\
(\% 6) \\
\end{array}$ & - & $\begin{array}{c}4 \\
(\% 11)\end{array}$ & $\begin{array}{c}4 \\
(\% 6) \\
\end{array}$ & $\begin{array}{c}1 \\
(\% 1)\end{array}$ & $\begin{array}{c}1 \\
(\% 1)\end{array}$ & $\begin{array}{c}6 \\
(\% 17)\end{array}$ & $\begin{array}{c}3 \\
(\% 12) \\
\end{array}$ & $\begin{array}{c}1 \\
(\% 4)\end{array}$ & - & $\begin{array}{c}4 \\
(\% 11)\end{array}$ & - & $\begin{array}{c}1 \\
(\% 2) \\
\end{array}$ & $\begin{array}{c}2 \\
(\% 4) \\
\end{array}$ & $\begin{array}{c}3 \\
(\% 8)\end{array}$ & $\begin{array}{c}4 \\
(\% 4) \\
\end{array}$ & $\begin{array}{c}8 \\
(\% 9) \\
\end{array}$ & $\begin{array}{c}7 \\
(\% 8) \\
\end{array}$ & $\begin{array}{c}19 \\
(\% 53)\end{array}$ & $\begin{array}{c}36 \\
(\% 14)\end{array}$ \\
\hline $\begin{array}{c}\text { VERİ } \\
\text { ANALIZİ }\end{array}$ & $\begin{array}{c}14 \\
(\% 42)\end{array}$ & $\begin{array}{c}10 \\
(\% 30)\end{array}$ & - & $\begin{array}{c}24 \\
(\% 15)\end{array}$ & $\begin{array}{c}13 \\
(\% 20)\end{array}$ & $\begin{array}{c}30 \\
(\% 46)\end{array}$ & $\begin{array}{c}11 \\
(\% 17)\end{array}$ & $\begin{array}{c}54 \\
(\% 32)\end{array}$ & $\begin{array}{c}9 \\
(\% 36)\end{array}$ & $\begin{array}{c}11 \\
(\% 44)\end{array}$ & $\begin{array}{c}1 \\
(\% 4)\end{array}$ & $\begin{array}{c}21 \\
(\% 13)\end{array}$ & $\begin{array}{c}6 \\
(\% 13)\end{array}$ & $\begin{array}{c}13 \\
(\% 30)\end{array}$ & $\begin{array}{c}5 \\
(\% 11)\end{array}$ & $\begin{array}{c}24 \\
(\% 15)\end{array}$ & $\begin{array}{c}15 \\
(\% 17)\end{array}$ & $\begin{array}{c}23 \\
(\% 27)\end{array}$ & $\begin{array}{c}4 \\
(\% 4)\end{array}$ & $\begin{array}{c}43 \\
(\% 25)\end{array}$ & $\begin{array}{c}165 \\
(\% 66)\end{array}$ \\
\hline $\begin{array}{c}\text { SONUÇLARI } \\
\text { YORUMLAMA }\end{array}$ & $\begin{array}{c}3 \\
(\% 9) \\
\end{array}$ & - & - & $\begin{array}{c}3 \\
(\% 9)\end{array}$ & $\begin{array}{c}2 \\
(\% 3) \\
\end{array}$ & $\begin{array}{c}1 \\
(\% 1)\end{array}$ & - & $\begin{array}{c}3 \\
(\% 9)\end{array}$ & - & - & - & - & $\begin{array}{c}5 \\
(\% 11) \\
\end{array}$ & $\begin{array}{c}9 \\
(\% 20) \\
\end{array}$ & - & $\begin{array}{c}14 \\
(\% 42)\end{array}$ & $\begin{array}{c}1 \\
(\% 1)\end{array}$ & $\begin{array}{c}6 \\
(\% 7) \\
\end{array}$ & $\begin{array}{c}6 \\
(\% 7) \\
\end{array}$ & $\begin{array}{c}13 \\
(\% 40)\end{array}$ & $\begin{array}{c}33 \\
(\% 13)\end{array}$ \\
\hline $\begin{array}{c}\text { İstatistik } \\
\text { Öğrenme Alanı } \\
\text { Ağırlığı }\end{array}$ & & (\%6) & & 574 & & $\begin{array}{c}64 \\
(\% 10)\end{array}$ & & 632 & & $\begin{array}{c}25 \\
(\% 5)\end{array}$ & & 467 & & $\begin{array}{c}43 \\
(\% 12)\end{array}$ & & 347 & & $\begin{array}{c}84 \\
(\% 30)\end{array}$ & & 275 & \\
\hline
\end{tabular}

Not: Tablodaki oranların temsil ettiği ifadeler, karıșıklık olmaması açısından her durum için verilen örnekler üzerinden açıklanmıştır.

*ilgili oran, ülkelerin ilgili aşama ve seviyelere dair kazanım sayılarının, matematik öğretim programlarındaki istatistik öğrenme alanına ilişkin toplam kazanım sayılarına bölünmesi ile elde edilmiştir.

(Örn. Türkiye toplamda 33 istatistik kazanımına sahip olup, problem durumu belirleme aşamasında A seviyesine ait 1 kazanım yer aldı̆̆ından bu oran \% 3 olarak hesaplanmıştır.)

** İlgili oran, ilgili istatistiksel süreç aşamasına yönelik her ülkenin yer verdiği toplam kazanım sayısının, tüm ülkelerin o aşama için toplam kazanım sayısına bölünmesi ile elde edilmiştir.

(Örn. Ülkelerin ögretim programlarında problem durumu belirleme aşamasına yönelik toplamda 15 kazanım yer almakta olup Türkiye’nin bu aşamaya ait 2 kazanımı olduğu için bu oran \%13 olarak hesaplanmıştır.)

*** Illgili oran, genel olarak belirli istatistiksel süreç așamasına yönelik kazanım saylsının, tüm așamalar için bulunan toplam kazanım saylsina bölünmesi ile elde edilmiștir.

(Örn. İstatistiksel süreç aşamalarına yönelik toplam 249 kazanımın 15'i problem durumu belirleme așamasına ait olduğu için oran \%6 olarak hesaplanmıştır.)

**** Ilgili oran, her ülkenin istatistik ögrrenme alanı ile ilgili toplam kazanım sayllarının matematik ögretim programındaki toplam kazanım sayısına bölünmesi ile elde edilmiştir.

(Örn. Türkiye’nin matematik öğretim programında yer alan toplam 574 kazanımın 33 ’ü istatistik öğrenme alanına ait olduğu için bu oran \%6 olarak hesaplanmıștır.) 
Tablo 3 incelendiğinde, tüm ülkeler içerisinde Yeni Zelanda'nın matematik öğretim programında istatistik öğrenme alanına ilişkin kazanım sayısının daha fazla olduğu görülmektedir. Bunun yanı sıra istatistik kazanımlarının oranları karşılaştırıldığında, Yeni Zelanda'nın en yüksek orana sahip olduğu (\%30) göze çarpmaktadır. Singapur'un istatistik öğrenme alanına ilişkin toplam kazanım sayısı açısından ikinci sırada bulunmasına karşın, bu ülkenin istatistik kazanımlarının öğretim programındaki payı açısından üçüncü sırada (\%10) yer alarak Amerika’yı (\%12) takip ettiği görülmektedir. Bununla birlikte, istatistik öğrenme alanına ilişkin en az kazanıma sahip olan ülkenin Kore olduğu görülmektedir. Türkiye'nin istatistik kazanımları sayıca Kore'den daha fazla olmasına rağmen, bu kazanımların öğretim programındaki ağırlığı açısından Kore (\%5) ve Türkiye (\%6) yakın yüzdelere sahiptir. Bu durum Kore ve Türkiye'nin istatistik kazanım sayısı ve bu kazanımların öğretim programındaki ağırlığı açısından diğer ülkelere kıyasla daha zayıf bir profil çizdiğini göstermektedir.

Tablo 3'teki istatistik kazanımları istatistiksel süreç aşamaları ve ilişkili olduğu seviyeler açısından incelendiğinde, genel olarak her bir aşamada A ve B seviyesinde yer alan kazanım sayısının daha fazla olduğu görülmektedir. Bununla birlikte, genel olarak veri analizi aşamasına dair kazanımların fazlalığı dikkat çekmektedir. Nitekim ülkelerin hepsinin öğretim programlarında bu aşamaya ayırdıkları kazanım sayılarının daha fazla olduğu görülmektedir. Bu aşamaya yönelik kazanım sayısı, tüm aşamalardaki toplam kazanımların \%66'sını oluşturmaktadır. Ayrıca her üç seviyeyi yansıtacak kazanımlara diğer aşamalara kıyasla veri analizi aşamasında daha fazla yer verildiği de görülmektedir. Ülkelerin bu aşamada en fazla B seviyesine ilişkin kazanıma sahip olduğu ve Singapur'un bu anlamda ön plana çıkmaktadır. Singapur \%32'lik bir oranla diğer ülkelere kıyasla bu aşamaya yönelik daha fazla kazanıma yer vermekte ve kazanımlarının \%83'ü veri analizi aşamasında yer almaktadır. Nitekim bu kazanımların \%46'sının B seviyesi ile ilişkili olduğu görülmektedir. Veri analizi aşamasında C seviyesindeki kazanımların yine Singapur'da daha yüksek yüzdeye (\%17) sahip olduğu dikkat çekmektedir. Örneğin; Singapur'da ortaöğretim sonrası ve üniversite öncesi dönemde seçmeli olarak sunulan $\mathrm{H} 1, \mathrm{H} 2$ ve $\mathrm{H} 2 \mathrm{~F}$ matematik öğretim programlarındaki veri analizinde $\mathrm{C}$ seviyesi ile ilişkili olarak örnekleme yöntemleri, örnekleme dağılım, güven aralığ 1 , hipotez testi, korelasyon, regresyon, en küçük kareler yöntemi gibi çıkarımsal istatistik konularına ilişkin anlamaların ön planda olduğu görülmektedir. Ülkelerin öğretim programlarında yer verdikleri konular, bu konuların yer aldığı sınıf seviyeleri ve bu sınıf seviyeleri kapsamında toplam kazanım sayıları Ek 2'de verilmiştir. Örneğin; H4.4 (korelasyonun anlamı), HF1.6 (güven aralı̆̆ı), H3.3 (hipotez testi) gibi kazanımlar çıkarımsal istatistiğin konu ve kavramlarına yöneliktir (bkz. Ek 1-Tablo 6). Veri analizi aşamasında A seviyesi ile ilişkili kazanımlara yer verme açısından Türkiye'nin öne çıktığı görülmektedir. Ülkemizde bu aşama ve seviye ile ilişkili kazanımların öğretim programındaki ağırlığ 1 diğer ülkelere kıyasla daha fazladır (\%44). Buna karşın Türkiye'de çıkarımsal istatistik konularına veya bu konulara zemin oluşturacak ölçüde herhangi bir kazanıma yer verilmediği tespit edilmiştir. $\mathrm{Bu}$ durum, ülkemizde veri analizi aşamasında $\mathrm{C}$ seviyesinde herhangi bir kazanımın yer almadığını göstermektedir. Kore, Amerika ve Yeni Zelanda'da verilerin analizi aşamasına yönelik fazla sayıda kazanım olmasına rağmen normal dağılım, korelasyon, regresyon, hipotez testi ve güven aralığı gibi çıkarımsal istatistiğge vurgu yapan C seviyesi ile ilişkili kazanımlara sınırlı olarak yer verildiği görülmektedir. Örneğin; Kore'de lise düzeyinde çıkarımsal istatistik ile ilgili olarak sadece L.9.5 (normal dağılımın anlamı) kazanımına yer verilerek çıkarımsal istatistik konuları normal dağılımın anlaşılması ile sınırlı kalmaktadır (bkz. Ek 1Tablo 9). Öte yandan istatistiksel sürecin başlatılması ve sağlıklı bir şekilde planlanması için en önemli aşama olan problem durumunu belirlemeye ilişkin kazanımlara tüm ülkelerde daha düşük oranda yer verildiği görülmektedir. Nitekim bu aşamaya yönelik kazanım oranının (\%6) tüm aşamalar içerisinde en az olduğu dikkat çekmektedir. Kore'de bu aşamaya yönelik herhangi bir kazanım bulunmazken; Singapur, Amerika ve Türkiye' de ise A ve B seviyelerinde az sayıda kazanıma yer verilmektedir. Problem durumunu belirleme aşaması istatistiksel sürecin ilk adımı olduğu için bu ülkelerde bu aşamaya yönelik sınırlı kazanım olması ve ileri düzeyde anlamaları sorgulayan C seviyesi ile ilişkili kazanımların yer almaması bir sınırlılık olarak görülmektedir. Bununla birlikte Yeni Zelanda'da \%67'lik bir oranla bu aşamaya daha fazla yer verilirken; aynı zamanda $\mathrm{C}$ seviyesini yansıtan kazanımların da yer aldığı görülmektedir. Yeni Zelanda'da istatistiksel süreç kullanılarak problemin belirlenmesi, ilişki ve karşılaştırmalara dayalı araştırma sorularının oluşturulması, birbirinden farklı ve bağımsız problemlerin araştırılması gibi problem durumunun belirlenmesine yönelik daha çok sayıda kazanıma rastlanmaktadır. Bununla birlikte, öğrencilerin çıkarım yapması ve eleştirel düşünmesine firsat veren sonuçların yorumlanması aşamasına yönelik kazanımların tüm ülkelerde az olduğu ve bu aşamanın problem durumunu belirleme aşamasını takip ettiği görülmektedir. Bu aşamaya yönelik kazanım sayısının tüm aşamalar içerisindeki oranının \%13 olduğu ve genellikle kazanımların B seviyesinde yoğunlaştığı dikkat çekmektedir. Diğer ülkelere kıyasla sonuçların yorumlanmasında \%42'lik oran ile Amerika daha fazla kazanıma yer vermektedir. Amerika'da bu aşamaya A (\%11) ve B (\%20) seviyeleri açısından diğer ülkelere oranla daha fazla ağırlık verilmektedir. $\mathrm{Bu}$ iki seviyede veri özetleme, tablo ve grafikleri yorumlama, korelasyon katsayısına dayalı temel çıkarımda bulunma gibi konular sunulmaktadır. Örneğin; HSS.ID.C.8 (korelasyon katsayısını yorumlama) kazanımı iki değişken arasında belirlenen ilişkinin gücünün yorumlanması ve değişkenlerin birbirlerine göre durumlarının ortaya konulması açısından B seviyesiyle ilişkiliyken; HSS.IC.B.6 (verileri yorumlama) kazanımı ise açıkça verilen bir veri seti üzerinde çalışarak temel düzeyde 
yorumlamayı gerekli kıldı̆̆ında A seviyesinin göstergeleri ile uyum göstermektedir (bkz. Ek 1-Tablo 7). Kore'de bu aşamaya dair herhangi bir kazanıma yer verilmezken, Türkiye'de sonuçların yorumlanması A seviyesi ile sınırlı kalmaktadır. Amerika'da bu aşamaya ilişkin $\mathrm{C}$ seviyesinde herhangi bir kazanım bulunmazken, Yeni Zelanda öğretim programının \%7'lik kısmı C seviyesine ayrılmıştır. Örneğin, Amerika'dan farklı olarak Yeni Zelanda'da L5.3.1.1 (örneklem dağılımlarını karşılaştırma) kazanımı ile örnekleme dağılımına yönelik $\mathrm{C}$ seviyesiyle ilişkili bir kazanım bulunmaktadır. Bu ülkede ayrıca bir veri setindeki değerleri kullanarak bu veri seti kapsamında oluşabilecek durumları kestirmek (interpolasyon), veri setinin dışına çıkarak ileriye dönük çıkarımlarda bulunmak (ekstrapolasyon) gibi çıkarımsal istatistiğe daha derinlemesine yer verilmektedir. Bunun sonucunda tahminde bulunma, örnekleme hatalarını tespit etme, merkezi limit teoremini kullanarak ortalama için tahminde bulunma gibi B ve C seviyeleriyle ilişkili kazanım sayısının fazla olduğu görülmektedir. Örneğin; L7.2.1.2.b (popülasyon parametresi kestirimi) kazanımı, veri ötesini okumayı ve genelleme yapmayı gerektiren C seviyesi ile ilişkili iken, belli bir istatistiksel durumu yansıtacak örneklemin belirlenmesinde gruplar arası karşılaştırmanın baskın olarak yapıldığı B seviyesiyle ilişkili L7.2.2.1.b (örnekleme hatasını belirleme) kazanımı yer almaktadır (bkz. Ek 1-Tablo 8). Diğer taraftan, genel olarak ülkelerin veri toplama aşaması ile ilişkili kazanımlarının her üç seviyede birbirine yakın olduğu görülmektedir. $\mathrm{Bu}$ anlamda kazanımların seviyelere göre en dengeli dağılımının veri toplama aşamasında olduğu söylenebilir. Bu aşamaya ait kazanımlar istatistiksel süreç aşamaları içerisinde \%14'lük bir yüzdeye sahiptir. Bununla birlikte, Amerika'da bu aşamayı A seviyesinde yansıtacak kazanıma rastlanmazken, Türkiye ve Kore'de ise bu aşamaya yönelik C seviyesi ile ilişkili kazanım bulunmamaktadır. Singapur'un H2 matematik öğretim programında popülasyon-örneklem ilişkisini rastgelelik kavramı odağında değerlendiren H2.1 (rastgele örneklem seçimi) kazanımı C seviyesinde yer almaktadır (bkz. Ek 1-Tablo 6). Veri toplama aşamasına diğer ülkelere kıyasla \%53'lük bir yüzde ile Yeni Zelanda' da daha fazla ağırlık verilmektedir. Yeni Zelanda aynı zamanda bu aşamayı B ve C seviyesindeki kazanımları ile yansıtması bakımından ön plana çıkmaktadır. Nitekim Yeni Zelanda'da veri toplama aşaması altında her iki seviyeye verilen ağırlığın (B: \%9 ve C: \%8) diğer ülkelere kıyasla daha fazla olduğu görülmektedir. Bu ülkede çok değişkenli veri setleri, rastgele seçimler, temsil edilebilirlik, örneklem seçiminin sınılılıkları, deneysel tasarımlar gibi B ve C seviyelerine örnek teşkil edecek konu ve kavramlara yer verilmektedir. Örneğin; 8.3.1.1 (veri seti üretme) kazanımı birden fazla değişkenin ilişkilendirilmesi sonucunda veri grupları üretilmesini gerekli kıldığından B seviyesi ile ilişkili olarak ele alınırken; L7.2.1.1.a (rastgele örneklemeye dayalı deneysel tasarımlar) kazanımı rastgelelik kavramının anlamlandırılması açısından C seviyesini yansıtmaktadır (bkz. Ek 1-Tablo 8). Tablo 3 'te frekans ve yüzde olarak belirtilen kazanımların içerikleri açısından dağılımını yansıtan her bir ülkeye ait tablolar Ek 1'de sunulmuştur. Tablolarda kazanımların numarası belirtilip içeriklerinin yer aldığı internet sitelerinin erişim adresleri de verilmiştir.

\section{Tartışma ve Sonuç}

Problem durumunu belirleme ile başlayan veri toplama, veri temsili-analizi ve çıkarımda bulunma şeklinde devam eden aşamalar istatistik okuryazarlığının temelini oluşturmaktadır (Watson, 2006). Aynı zamanda bir istatistiksel süreç oluşturan bu aşamaların daha etkili bir istatistik öğretimi için bütüncül bir şekilde ele alınmasının gerekliliği belirtilmektedir (Newton, Dietiker, \& Horvath, 2011). Bu anlamda bireylerin yürüttükleri araştırmalarda daha aktif katılıma ve etkili bir süreç yönetmelerine olanak tanıyan istatistiksel sürecin bir bütün olarak ele alınması (her bir aşamasının döngüsel olarak izlenmesi) son derece önemli olmaktadır. Bununla birlikte sadece istatistiksel süreci yansıtan uygulamalara yer verilmesi yeterli görülmeyerek bu uygulamaların etkili ve kalıcı bir istatistik öğretimine zemin oluşturacak şekilde tasarlanmasının da altı çizilmektedir (Franklin vd., 2007). Bunun yanı sıra, GAISE raporunda sunulan kuramsal çerçeveye dayalı analizlerin, istatistik öğretimini şekillendiren öğretim programlarının bu yönde eğilimlerinin belirlenmesinde önemli olduğu düşünülmektedir. Bu anlamda ülkelerin matematik öğretim programlarında yer alan istatistik kazanımları GAISE raporunun üzerinde önemle durduğu istatistiksel süreç aşamaları açısından incelenmiştir. Araştırma sonuçları, diğer ülkelere oranla Türkiye'de matematik öğretim programında yer verilen istatistik kazanımlarının hem sayısal olarak hem de ilişkili olduğu seviye açısından daha düşük düzeyde ele alındığını göstermektedir. Ülkemizdeki istatistik kazanımları sadece A ve B seviyesinde yer alırken, diğer ülkelerde B ve C seviyesini yansitacak kazanımların daha fazla olduğu tespit edilmiştir. Özellikle Singapur ve Yeni Zelanda'nın bu anlamda ön plana çıtığı görülmüştür. Bu durumun dünya genelindeki ülkelerin katılımıyla düzenlenen PISA ve TIMSS sınav sonuçlarına da yansıdığı düşünülmektedir. Nitekim istatistik öğrenme alanına ilişkin öğrencilerin okuryazarlık, muhakeme gibi yeterliklerini ölçmeyi gerektiren problemlerde Türkiye diğer ülkelerin başarı ortalamasının oldukça altında yer almaktadır (PISA, 2015; TIMSS, 2015). Bu durumun, öğretim programındaki istatistik konu ve kazanımlarının istatistik okuryazarlığından ziyade temel istatistik bilgisi kazandırma yönünde bir eğilim göstermesinden kaynaklandığı düşünülmektedir. Öğretim programımızda da diğer ülkelerde görüldüğ̈̈ gibi $\mathrm{B}$ ve $\mathrm{C}$ seviyelerinde yoğunlaşan, çıarımsal istatistik konularına en azından zemin oluşturacak nitelikte konu ve kazanımlara yer verilmesine ihtiyaç duyulmaktadır. Ülkemizde her ne kadar istatistik okuryazarlığı, istatistiksel muhakeme ve düşünmeye yönelik çalışmalarda bir artış görülse de bu çalışmaların ortak bir sonucu olarak öğrencilerin, öğretmenlerin ya da bireylerin istatistiksel bilgi ve donanım açısından eksikliklerine dikkat 
çekilmektedir (Koparan, 2012; Özmen, 2015; Reston 2005). Bu anlamda bu tür çalışmaların sonuçları ancak öğretim programında ve devamında istatistik öğretimlerinde değişikliğe gidilmesiyle bir anlam ifade edecektir. Aksi halde sadece mevcut durumun resmedilmesi ile sınırlı kalmaktadır. Bu anlamda GAISE raporunda yer alan daha üst seviyelere yönelik konu ve kazanımların öğretim programımıza dâhil edilmesi ile ilgili çalışmaların başlatılması son derece önem arz etmektedir.

Genel olarak ülkelerin istatistik öğrenme alanındaki kazanımlarının istatistiksel süreç aşamalarına göre dağılımı incelendiğinde, problem durumunun belirlenmesi ve elde edilen sonuçların yorumlanması aşamalarına dair kazanımlara daha az, veri analizi aşamasına ilişkin kazanımlara ise daha fazla yer verildiği görülmüştür. Veri analizi aşamasının doğası gereği farklı ölçüm ve temsiller yardımıyla veri grubunu özetlemeyi gerektirmesinin bu sonuç üzerinde etkili olduğu düşünülmektedir. Benzer şekilde yapılan çalışmalarda da genellikle istatistiksel sürecin veri analizi ve veri temsili aşamasının ön planda olduğu, problem durumunun belirlenmesi ve verilerin yorumlanması aşamalarınınise eksik kaldığı görülmektedir (Koparan, \& Güven, 2013; Money, 2002). Bu anlamda farklı istatistiksel süreç aşamalarına yoğunlaşan araştırmalar yapılması ve bu araştırmaların sonuçlarına bağlı olarak öğretim programlarında da gerekli düzenlemeler yapılması önemli bir girişim olacaktır. Her ne kadar verilerin uygun gösterimlerle temsili ve uygun yöntemler kullanılarak analizi, istatistik okuryazarlığı için önemli göstergeler olsa da (Steen, 1999) bu tür temsil ve analizlere başvurulması için süreci başlatacak uygun nitelikte bir problem durumunun belirlenmesi ve ulaşılan sonuçların eleştirel bir gözle değerlendirilerek yorumlanması da oldukça önemlidir. Nitekim problem durumunun belirlenmesi bir araştırma sürecini başlatan ilk adım olup bu aşamaya yönelik yeterli bilgi sahibi olunmaması veya etkili bir problem durumunun ortaya koyulamaması diğer aşamaları da olumsuz etkileyecektir. $\mathrm{Bu}$ anlamda öğretim programlarında problem durumunun belirlenmesi, amaca uygun olan ve olmayan problemlerin ne tür sonuçlar çıkarılabileceğine yönelik kazanımlara yer verilmesi önemli görülmektedir. Diğer taraftan, bir araştırma sürecinin sonunda ulaşılan sonuçların yorumlanmasına yöneliksınırlı uygulamaların farklı yorumların ve tartışmaların ortaya çıkmasının önüne geçerek istatistiksel sürecin döngüsel olmasını olumsuz yönde etkileyeceği düşünülmektedir Ülkelerin matematik öğretim programlarında yer verilen kazanım sayısının istatistiksel sürecin her bir aşamasını yansıtacak yapıda olmaması, istatistiksel süreç aşamalarının öğrenciler tarafindan tam olarak anlaşılmasına engel oluşturabilir. Bu durum ise istatistik okuryazarlığının önemli bir göstergesi niteliğinde olan istatistiksel sürecin deneyim edilmesine ilişkin problemleri de beraberinde getirecektir. Dolayısıyla istatistik öğrenme alanında öğrencilerin istatistiksel sürecin her bir aşamasını deneyimlemelerini sağlayacak yönde kazanımlara yer verilmesinin bu tür problemlerle baş etmede önemli bir girişim niteliğinde olacağ 1 düşünülmektedir.

Ülkelerin istatistik öğrenme alanı kapsamında ele aldıkları kazanımların sayısı ve içeriğindeki farklılıklar, aynı zamanda öğrencilerin istatistiğe yönelik edindikleri bilgi ve becerilerin gelişiminde önemli bir belirleyici olduğu düşünülmektedir. Örneğin Singapur'da istatistik kazanımları temel kavramlardan çıkarımsal istatistiğe doğru giden bir yapıda ve sayıca fazla iken, ülkemizde bu kazanımların sayıca daha az ve daha düşük seviyelerle ilişkili olduğu görülmektedir. Bu tür farklılıkların uluslararası sınavlarda ve yapılan araştırmalarda ülkelerin istatistik alanındaki yerini belirleyen önemli bir etken olduğu düşünülmektedir. Nitekim istatistik kazanımlarının temel istatistiksel kavramlardan çıkarımsal istatistiğe doğru bir yapıda ve yeterli sayıda ele alınmasının adına başarılı çıktılar elde edilmesi ve ülkeler arasındaki farklı başarı seviyelerinin ortaya çıkmasında etkili olduğu düşünülmektedir. Çıkarımsal istatistiğe ağırlık verilen etkili bir istatistik öğretimi ile yetişen öğrencilerin akıl yürütme, muhakeme, eleştirel düşünme gibi üst düzey becerilerinde önemli gelişmeler olacaktır. Örneğin, bir öğrencinin değişkenler arasındaki ilişki konusunda yeterli bilgiye sahip olarak üniversiteye gelmesi korelasyon ve regresyon konularında ilişki kavramı, değişkenler arasındaki ilişkiyi anlamlandırma ve yorumlamada yardımcı olacağı düşünülmektedir. Güven aralığı ve hipotez testi için temel oluşturan fikirleri öğrenmiş bir öğrencinin de hipotez oluşturma, oluşturduğu hipotezleri belirli güven aralıklarında test ederek bu doğrultuda bir karara varma gibi bilgi ve becerilerinin gelişimine büyük ölçüde katkı sağlayacaktır. Dolayısıyla bu durum hem kişisel hem iş yaşamlarında her gün yeni ve etkili kararlar almaları gereken bireylerin işini şansa bırakmalarını değil, istatistik bilgi ve becerisine dayalı olarak fikirler üretmelerini sağlayacaktır. Ayrıca sahip olduğu istatistik bilgisini istatistiksel sürecin aşamalarına göre ele alabilen öğrencilerin aynı zamanda iyi birer problem çözücü olarak yetişeceği de belirtilmektedir (Neumann, Hood, \& Neumann, 2013). Bu anlamda matematik öğretim programlarında istatistik öğrenme alanına en azından çıkarımsal istatistiğe zemin oluşturacak kazanımların eklenmesi istatistik eğitimi için önemli bir girişim olacaktır.

Ülkemizde matematik öğretim programında istatistik konularının daha dar bir kapsamda ele alınması, öğrencilerin çevrelerinde karşılaşacakları durumları istatistiksel olarak değerlendirirken yaşayacakları zorluğun en büyük habercisi olarak görülmektedir. Verilerle kuşatılmış günümüz dünyasının başrollerinden birisi olan istatistik; ortalama, standart sapma, grafik (sütun, çizgi, daire vb.) gibi temel kavramları bilmekten çok daha fazlasını içermektedir. Bu anlamda istatistik öğrenme alanına ilișkin öğretimlerin daha nitelikli olması ve daha etkili öğrenme ortamlarının tasarlanmasında istatistiksel düşünme, muhakeme ve okuryazarlık gibi yeterliklerin temel alınması ve istatistiksel sürece ağırlık verilmesi önem arz etmektedir. Ancak; ülkemiz matematik öğretim programında istatistik öğrenme alanı içerisinde ele alınan kazanım sayısı ve içeriği bu isteği karşılayacak 
yeterlikte değildir. Çoğunlukla A ve B seviyesindeki kazanımlara yer verilmesinin istatistiksel anlamda üretken öğrencilerin yetiştirilmesini zorlaştıracağı ifade edilmektedir (Koparan, 2012; Yolcu, 2012). Bu eksikliği gidermek için hem istatistik öğrenme alanına ilişkin kazanım sayısının arttırılması hem de bu kazanımların içeriğinin istatistiğe ilişkin temel bilgi ve fikirler kullanılarak akıl yürütme, muhakeme, eleştirel yaklaşım gibi becerilerin geliştirilmesine imkân verecek yönde düzenlenmesinin gerekli olduğu düşünülmektedir. Nitekim istatistik eğitimi ile ilgili yapılan çalışmalarda da istatistik öğretiminin niteliğinin artırılması ve öğrencilerde istatistik eğitimi için önemli görülen yeterliklerin geliştirilmesi gerektiği vurgulanmaktadır (Akoğlu, 2018; Chick, \& Pierce, 2008; Garfield, \& delMas, 2010). Öğrencilerden beklenen bilgi ve becerilerin gelişiminde C seviyesine yönelik kazanımlara yer verilmesinin önemi açıç̧a görülmektedir. Sadece A ve B seviyesi ile sınırlandırılmış bir öğretim programı ve buna bağlı olarak şekillenen istatistik öğretiminden çağın gerektirdiği istatistiksel düşünme ve muhakeme yeterliliğine sahip bireyler yetiştirilmesini beklemek mümkün olmayacaktır. $\mathrm{Bu}$ beklentiye ulaşılmasında öğretim programlarında her bir aşamaya yönelik farklı seviyeleri temel alan kazanımlara yer verilmesi önerilmektedir. Öğrencilerin istatistik okuryazarlığı, istatistiksel düşünme ve muhakeme yeterlilikleri açısından donanımlı olarak yetişmelerinde uygun istatistik öğretimlerinin öneminden bahsedilmektedir (Callingham, \& Watson, 2017; Groth, 2017; Özmen, \& Baki, 2017). Öğretim programları sınıflarda yapılan öğretimlerin şekillendirilmede önemli bir rol üstlense de iyi bir programının tasarımı kadar sınıf içi uygulamaların etkliliği de son derece önem arz etmektedir. Nitekim öğretim programı daha üst seviyelerde konu ve kazanımları işaret etse de bunu uygulayacak olan öğretmenlerdir. Bu durum aynı zamanda istatistik öğretimine dikkat çekilmesine işaret etmektedir. Literatürde de istatistik öğrenme alanına ilişkin konu ve kazanımların sınırlı ele alınması kadar bu konuların öğretiminde öğretmenlerin yetersiz oldukları veya kendilerini yetersiz hissettiklerinden bahsedilmektedir. Bu anlamda ilk olarak ülkemizde matematik öğretim programındaki istatistik öğrenme alanının yeniden gözden geçirilmesi önerilmektedir. Daha sonra yenilenen öğretim programı doğrultusunda istatistik öğretimlerinin iyileştirilmesi ve buna bağlı olarak çıktıların istatistik eğitimi için belirlenen nihai hedefler doğrultusunda incelenmesine yönelik çalışmalar yapılabilir.

Farklı ülkelerin matematik öğretim programlarının istatistik öğrenme alanı açısından karşılaştırılmasına yönelik yapılan bu çalışmada bazı sınırlılıklar yer almaktadır. Bu çalışmada ülkelerin matematik öğretim programlarında yer alan istatistik öğrenme alanına ilişkin kazanımlar GAISE raporunda yer alan kuramsal çerçeve doğrultusunda sadece öğretim programında belirtilen ifade ve açıklamalara bağlı olarak incelenmiştir. Mevcut sınırlılık kapsamında, bu ülkelerdeki istatistik öğretimlerinin nasıl şekillendirildiği tam olarak anlaşılamamaktadır. Bu noktada, ülkelerin matematik ders kitaplarının incelenmesi ya da istatistik öğretimlerinin bizzat öğrenme ortamında gözlemlenerek daha detaylı karşılaş̧ırmalar yapılması önerilmektedir. Ayrıca bu çalışmadan elde edilen sonuçlar doğrultusunda, öğretim programımızda gerekli düzenlemelerin yapılması istatistik öğretimi sonucunda daha etkili öğrenme çıktıları oluşmasına katkı sunacaktır.

\section{EK 1}

Tablo 5. Türkiye istatistik öğrenme alanı kazanımlarının dağılımı (bkz: http://www.meb.gov.tr/)

\begin{tabular}{|c|c|c|c|}
\hline $\begin{array}{c}\text { İSTATISTIKSEL SÜREÇ } \\
\text { AŞAMALARI }\end{array}$ & A SEVIYYESI & B SEVIYYESİ & C SEVIYESI \\
\hline $\begin{array}{l}\text { PROBLEM DURUMUNU } \\
\text { BELİRLEME }\end{array}$ & M.5.3.1.1. & M.6.4.1.1. & - \\
\hline $\begin{array}{c}\text { VERİ } \\
\text { TOPLAMA }\end{array}$ & M.2.4.1.1. M.5.3.1.2. & M.4.4.1.3 (M.6.4.1.1.) & - \\
\hline $\begin{array}{c}\text { VERI } \\
\text { ANALIZI }\end{array}$ & $\begin{array}{l}\text { M.1.4.1.1. M.3.4.1.3. M.4.4.1.2. } \\
\text { M.5.3.1.3. M.6.4.1.2. M.6.4.2.1. } \\
\text { M.6.4.2.2. M.7.4.1.1. M.8.4.1.1. } \\
\text { (M.2.4.1.1 M.5.3.1.2 M.9.5.1.1.) } \\
\text { M.4.4.1.4. }\end{array}$ & $\begin{array}{l}\text { M.3.4.1.1.M.3.4.1.2.-M.6.4.2.3. } \\
\text { M.7.4.1.2.-M.7.4.1.3.M.7.4.1.4. } \\
\text { M.8.4.1.2.-M.9.5.2.2.(M.4.4.1.3.) }\end{array}$ & - \\
\hline $\begin{array}{l}\text { SONUÇLARI } \\
\text { YORUMLAMA }\end{array}$ & M.9.5.1.1. (M.6.4.2.1.M.6.4.2.2.) & - & - \\
\hline
\end{tabular}


Tablo 6. Singapur istatistik öğrenme alanı kazanımlarının dağılımı (bkz: https://www.moe.gov.sg/)

\begin{tabular}{|c|c|c|c|}
\hline $\begin{array}{c}\text { ISTATISTIKSEL SÜREÇ } \\
\text { AŞAMALARI }\end{array}$ & A SEVIYYESİ & B SEVIYYESİ & C SEVIYYESİ \\
\hline $\begin{array}{l}\text { PROBLEM DURUMUNU } \\
\text { BELİRLEME }\end{array}$ & - & P2.1. & - \\
\hline $\begin{array}{c}\text { VERİ } \\
\text { TOPLAMA }\end{array}$ & P1.1. P3.1. SO1.2. P4.2. & (P2.1.) & $* \mathrm{H} 2.1$ \\
\hline $\begin{array}{c}\text { VERI } \\
\text { ANALIZI }\end{array}$ & $\begin{array}{c}\text { P1.2 P1.3. P2.2. P3.2.P3.3. P5.1. } \\
\text { P6.3. SO1.1. H1.3. (P1.1., P3.1., } \\
\text { SO1.2. P4.2.) }\end{array}$ & 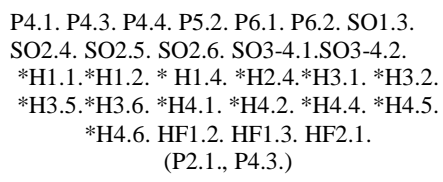 & $\begin{array}{c}* \mathrm{H} 2.2 .{ }^{*} \mathrm{H} 2.3 . * \mathrm{H} 2.5 * \mathrm{H} 3.3 . \\
* \mathrm{H} 3.4 . \\
\text { *H4.3. H4.7. HF1.1. HF1.4. } \\
\text { HF1.5. HF1.6. }\end{array}$ \\
\hline $\begin{array}{l}\text { SONUÇLARI } \\
\text { YORUMLAMA }\end{array}$ & P6.4. SO1.4. & $\mathrm{HF} 2.2$. & - \\
\hline
\end{tabular}

Tablo 7. Amerika istatistik öğrenme alanı kazanımlarının dağılımı (bkz. http://www.corestandards.org/Math/Content/)

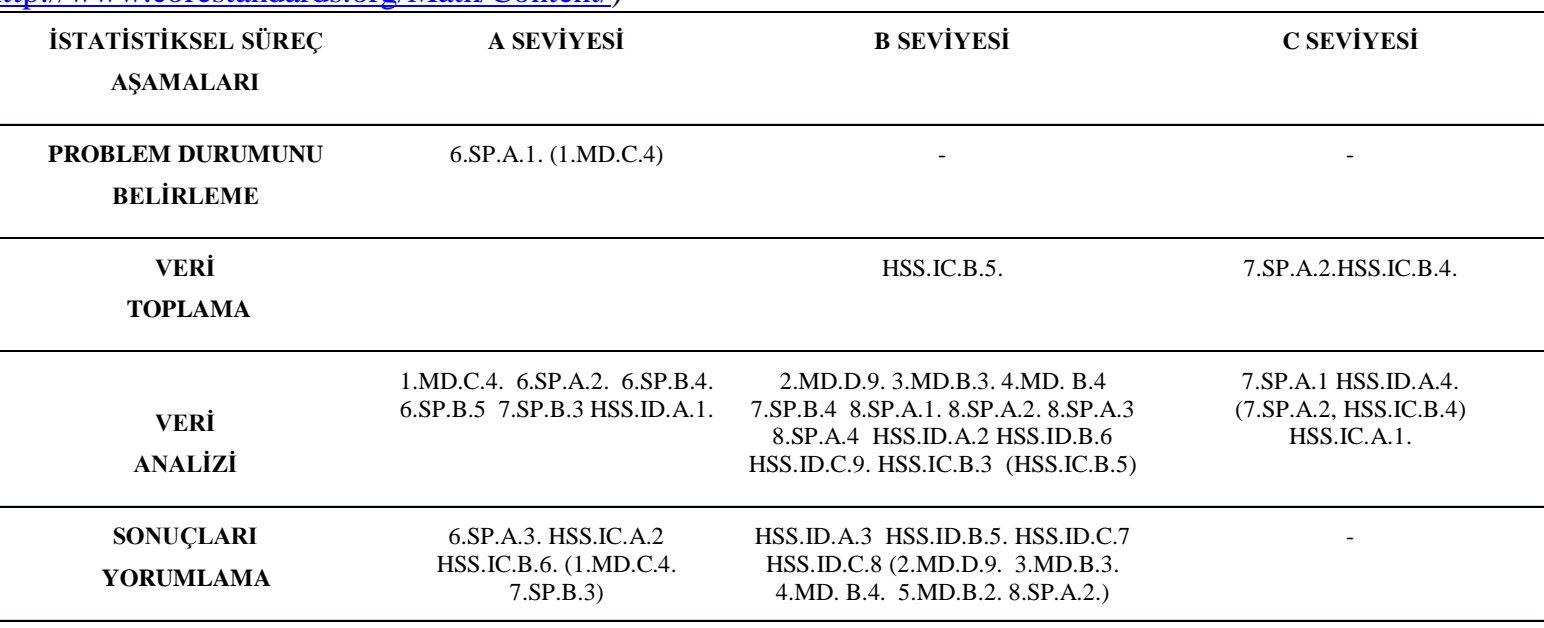

Tablo 8. Yeni Zelanda istatistik öğrenme alanı analizi (bkz: https://nz.ixl.com/standards/maths)

\begin{tabular}{|c|c|c|c|}
\hline $\begin{array}{l}\text { ISTATİSTIKSEL SÜREÇ } \\
\text { AŞAMALARI }\end{array}$ & A SEVIYYESİ & B SEVIYYESİ & C SEVIYYESİ \\
\hline $\begin{array}{l}\text { PROBLEM DURUMUNU } \\
\text { BELIRLEME }\end{array}$ & $\begin{array}{lll}1.3 .1 & 3.3 .1 & 4.3 .1\end{array}$ & $\begin{array}{l}2.3 .1-5.3 .1-6.3 .1 \\
\quad 7.3 .1-8.3 .1\end{array}$ & L7.2.1.1 -L8.2.1.1. \\
\hline $\begin{array}{c}\text { VERİ } \\
\text { TOPLAMA }\end{array}$ & $\begin{array}{l}\text { 2-Q.1 3.3.1.1 4.3.1.1 } \\
5.3 .1 .1\end{array}$ & $\begin{array}{l}\text { 6.3.1.1- 6.3.1.3- 7.3.1.1 } \\
\text { 8.3.1.1- L5.3.1.1 -L5.3.1.1. } \\
\text { L5.3.1.1.c- L7.2.1.1.b }\end{array}$ & $\begin{array}{l}\text { L5.3.1.1.b L5.3.2.1 (8-Z.5- } \\
\text { 8.3.1.3, 9-CC.6) } \\
\text { L6.3.1.1.b L7.2.1.1.a L8.2.1.1. } \\
(13-\text { R.15) }\end{array}$ \\
\hline $\begin{array}{c}\text { VERI } \\
\text { ANALIZI }\end{array}$ & $\begin{array}{l}1.3 .1 \text { (2-Q.2-2.3.1) 2-Q.3-2.3.1) } \\
3.3 .1 .2(3-R .4)(3-R .7) \text { 4-K.2- } \\
\text { 4.3.1.1-4.3.1.2 (4-K.4) (4-K.6) } \\
(4-K .8)(5-H .3-5.3 .1 .1)(5-H .5- \\
5.3 .1 .1)(5-H .7-5.3 .1 .1) 5.3 .1 .2 \\
(6-Q .2-6.3 .1 .1) 6-Q .3-6.3 .1 .1)(6- \\
\text { Q.10-6.3.1.1) (6-Q.11-6.3.1.1) }\end{array}$ & $\begin{array}{c}(2-\mathrm{Q} .4-2.3 .1)(3-R .2-3.3 .1 .1) \\
(3-\mathrm{R} .9-3.3 .1 .1)(5-H .11-5.3 .1 .1) 6.3 .1 .2 \\
\text { (6-Q.15) 6.3.1.3 (7-EE.16-7.3.1.1) } \\
\text { (7-EE.17-7.3.1.1) 7.3.1.2 (7-EE.18-7.3.1.2) } \\
\text { 7.3.1.3 -8.3.1.2 -8.3.1.3- L5.3.1.1.d } \\
\text { L5.3.1.1.e 8-Z.2, 9-CC.2, 10-BB.2) } \\
\text { (10-BB.4, 11-NN.2, 12-CC.2, 9-CC.5) } \\
\text { L6.3.1.1.a- L6.3.1.1.c- L6.3.1.1.e } \\
\text { L8.2.1.1.c -L8.2.1.1.d }\end{array}$ & $\begin{array}{l}\text { (10-BB.5, 11-NN.3, 12-CC.3) } \\
\text { (13-R.8) L7.2.1.1.c 13-R.4) }\end{array}$ \\
\hline $\begin{array}{c}\text { SONUÇLARI } \\
\text { YORUMLAMA }\end{array}$ & L5.3.1.1.f & $\begin{array}{c}\text { 7.3.1.3- L6.3.2.1- L7.2.1.2.a } \\
\text { L7.2.2.1-. L7.2.2.1.b -L8.2.1.1.c }\end{array}$ & $\begin{array}{l}\text { L6.3.1.1.d -L7.2.1.1.c } \\
\text { L7.2.1.2.b -L7.2.1.2.c } \\
\text { L8.2.1.1.b- L8.2.1.2.a }\end{array}$ \\
\hline
\end{tabular}


Tablo 9. Kore istatistik öğrenme alanı kazanımlarının dağılımı (bkz: http://ncic.re.kr/ )

\begin{tabular}{|c|c|c|c|}
\hline $\begin{array}{l}\text { İSTATISTTIKSEL SÜREÇ } \\
\text { AŞAMALARI }\end{array}$ & A SEVIYESI & B SEVIYYSİ & C SEVIYYESI \\
\hline $\begin{array}{l}\text { PROBLEM DURUMUNU } \\
\text { BELÍRLEME }\end{array}$ & - & İ.5.3 & - \\
\hline $\begin{array}{c}\text { VERİ } \\
\text { TOPLAMA }\end{array}$ & İ.1. İ.4.1. İ.3.1. & & - \\
\hline $\begin{array}{c}\text { VERI } \\
\text { ANALIZI }\end{array}$ & $\begin{array}{l}\text { İ.2.1 İ.3.2 İ.5.1. İ.5.2. L.9.1. L.9.4. } \\
\text { (İ.4.1. İ.3.1.) }\end{array}$ & $\begin{array}{c}\text { İ.2.2. İ.4.2. İ.4.3. O.6.1. O.6.2. } \\
\text { O.7.1. O.7.2. O.7.3. O.7.4. L.9.3. } \\
\text { (I.5.3.) }\end{array}$ & L.9.5. \\
\hline $\begin{array}{l}\text { SONUÇLARI } \\
\text { YORUMLAMA }\end{array}$ & - & - & - \\
\hline
\end{tabular}

EK 2

Tablo 10. İstatistik konuları ve verildikleri sınıf seviyelerinin ülkeler açısından dağılımı

\begin{tabular}{|c|c|c|c|c|c|c|}
\hline \multicolumn{2}{|c|}{ KAVRAMLAR } & \multicolumn{5}{|c|}{ ÜLKELER } \\
\hline & & TÜRKIYYE & SINGAPUR & KORE & AMERIKA & YENI ZELANDA \\
\hline \multirow{7}{*}{$\begin{array}{l}\text { Merkezi Eğilim } \\
\text { ve Yayilım } \\
\text { Ölçüleri }\end{array}$} & Aritmetik ortalama & $\begin{array}{l}6,7 \text { ve } 9 . \text { sinif } \\
\text { (4 K) }\end{array}$ & $\begin{array}{c}5,8,9 / 10 . \sin 1 f \\
(6 \mathrm{~K})\end{array}$ & $\begin{array}{l}5 \text { ve } 7 . \operatorname{sinif} \\
(2 \mathrm{~K})\end{array}$ & $\begin{array}{l}\text { 6,7. ve } 9 / 12 . \sin 1 \mathrm{f} \\
(5 \mathrm{~K})\end{array}$ & $\begin{array}{c}\text { 5., 8-10.sinif } \\
(4 \mathrm{~K})\end{array}$ \\
\hline & Medyan & $\begin{array}{l}7 \text { ve } 9 . \sin 1 f \\
(2 \mathrm{~K})\end{array}$ & $\begin{array}{l}\text { 8. sinıf } \\
(2 \mathrm{~K})\end{array}$ & $\begin{array}{l}\text { 9. sinif } \\
(2 \mathrm{~K})\end{array}$ & $\begin{array}{c}\text { 6-7.,9/12.sinıf } \\
(4 \mathrm{~K})\end{array}$ & $\begin{array}{c}\text { 5., 8-10.sinif } \\
(4 \mathrm{~K})\end{array}$ \\
\hline & Mod & $\begin{array}{l}7 \text { ve } 9 . \sin 1 f \\
(2 \mathrm{~K})\end{array}$ & $\begin{array}{l}\text { 8. sinif } \\
(2 \mathrm{~K})\end{array}$ & $\begin{array}{l}\text { 9. } \sin 1 f \\
(1 \mathrm{~K})\end{array}$ & $\begin{array}{c}\text { 6-7.,9/12.sinif } \\
(4 \mathrm{~K})\end{array}$ & $\begin{array}{c}\text { 5.,8-10.sinıf } \\
(4 \mathrm{~K})\end{array}$ \\
\hline & Standart Sapma & $\begin{array}{l}\text { 9. sinif } \\
(1 \mathrm{~K})\end{array}$ & $\begin{array}{c}9 / 10 . \text { sinif } \\
(2 \mathrm{~K})\end{array}$ & $\begin{array}{l}\text { 9. sinif } \\
(1 \mathrm{~K})\end{array}$ & $\begin{array}{c}\text { 9/12.sinıf } \\
(2 \mathrm{~K})\end{array}$ & $\begin{array}{c}\text { 8-9.sinıf } \\
(2 \mathrm{~K})\end{array}$ \\
\hline & Varyans & - & $\begin{array}{c}11 / 12 . \sin 1 f \\
(1 \mathrm{~K})\end{array}$ & $\begin{array}{l}\text { 9. sinif } \\
(1 \mathrm{~K})\end{array}$ & - & $\begin{array}{l}\text { 8-9.sinif } \\
(2 \mathrm{~K})\end{array}$ \\
\hline & Ranj & $\begin{array}{l}6 \text { ve } 9 . \text { sinif } \\
(3 \mathrm{~K})\end{array}$ & $\begin{array}{l}\text { 9/10. sinif } \\
(1 \mathrm{~K})\end{array}$ & $\begin{array}{l}\text { 9. } \sin 1 f \\
(1 \mathrm{~K})\end{array}$ & $\begin{array}{c}\text { 9/12.sinıf } \\
(1 \mathrm{~K})\end{array}$ & $\begin{array}{c}\text { 8-10.sinif } \\
(3 \mathrm{~K})\end{array}$ \\
\hline & $\begin{array}{l}\text { Ceyrekler ve } \\
\text { yüzdelikler }\end{array}$ & - & $\begin{array}{c}\text { 9-10. sinif } \\
(1 \mathrm{~K})\end{array}$ & - & $\begin{array}{c}\text { 6. ve } 9 / 12 . \operatorname{sinlf} \\
(1 \mathrm{~K})\end{array}$ & $\begin{array}{c}\text { 9-12.sinif } \\
(4 \mathrm{~K})\end{array}$ \\
\hline \multirow{10}{*}{$\begin{array}{l}\text { Tablo ve } \\
\text { Grafikler }\end{array}$} & Çetele/Sıklık tablosu & $\begin{array}{l}\text { 1-6. sinif } \\
(7 \mathrm{~K})\end{array}$ & $\begin{array}{c}4 \text { ve } 7 . \operatorname{sinif} \\
(2 \mathrm{~K})\end{array}$ & $\begin{array}{c}2,3 \text { ve } 7 . \text { sinif } \\
(4 \mathrm{~K})\end{array}$ & $\begin{array}{l}\text { 1. ve 8.sinif } \\
(2 \mathrm{~K})\end{array}$ & $\begin{array}{c}2 . \sin 1 f \\
(1 \mathrm{~K}) \\
\end{array}$ \\
\hline & Şekil grafiği & $\begin{array}{l}\text { 2-4. sinif } \\
(3 \mathrm{~K})\end{array}$ & $\begin{array}{c}1,2 \text { ve } 7 . \text { sinif } \\
(3 \mathrm{~K})\end{array}$ & $\begin{array}{c}2,3 \text { ve } 5 . \sin 1 f \\
(3 \mathrm{~K})\end{array}$ & $\begin{array}{c}2-3 . \operatorname{Snn} 1 \mathrm{f} \\
(2 \mathrm{~K})\end{array}$ & $\begin{array}{c}\text { 1-4.sinif } \\
(8 \mathrm{~K})\end{array}$ \\
\hline & Sütun grafiği & $\begin{array}{l}\text { 4-8. sinlf } \\
(8 \mathrm{~K})\end{array}$ & $\begin{array}{c}3,4 \text { ve } 7 . \sin 1 f \\
(6 \mathrm{~K})\end{array}$ & $\begin{array}{l}3 \text { ve } 4 . \sin 1 f \\
(2 \mathrm{~K})\end{array}$ & $\begin{array}{l}2-3 . \sin 1 f \\
(2 \mathrm{~K})\end{array}$ & $\begin{array}{c}2-7 . \sin 1 f \\
(5 \mathrm{~K})\end{array}$ \\
\hline & Çizgi grafiği & $\begin{array}{c}7 \text { ve } 8 . s i n i f \\
(4 \mathrm{~K})\end{array}$ & $\begin{array}{c}4 \text { ve } 7 . \text { Sinif } \\
(2 \mathrm{~K})\end{array}$ & $\begin{array}{c}4 . \sin 1 f \\
(2 \mathrm{~K})\end{array}$ & $\begin{array}{l}\text { 4-5.sinif } \\
(2 \mathrm{~K})\end{array}$ & $\begin{array}{c}\text { 4-7.sinif } \\
(7 \mathrm{~K})\end{array}$ \\
\hline & Daire grafiği & $\begin{array}{c}7 \text { ve } 8 . \sin 1 f \\
(3 \mathrm{~K})\end{array}$ & $\begin{array}{l}6 \text { ve 7.sinıf } \\
(4 \mathrm{~K})\end{array}$ & $\begin{array}{l}6 . \operatorname{sinlf} \\
(1 \mathrm{~K})\end{array}$ & $\begin{array}{c}9 / 12 . \sin 1 f \\
(1 \mathrm{~K})\end{array}$ & $\begin{array}{l}2 . \sin 1 f \\
(1 \mathrm{~K})\end{array}$ \\
\hline & Histogram & $\begin{array}{c}\text { 9. sinıf } \\
(1 \mathrm{~K})\end{array}$ & $\begin{array}{c}\text { 8. sinıf } \\
(1 \mathrm{~K})\end{array}$ & $\begin{array}{l}\begin{array}{l}7 . s n i f \\
(1 \mathrm{~K})\end{array} \\
\end{array}$ & $\begin{array}{c}\text { 6. ve } 9 / 12 . \operatorname{sinlf} \\
(2 \mathrm{~K})\end{array}$ & $\begin{array}{c}7 . \text { sinif } \\
(2 \mathrm{~K}) \\
\end{array}$ \\
\hline & Nokta grafiği & - & $\begin{array}{l}\text { 8. sinif } \\
(1 \mathrm{~K})\end{array}$ & - & $\begin{array}{l}\text { 6. ve } 9 / 12 . \operatorname{sinlf} \\
(2 \mathrm{~K})\end{array}$ & - \\
\hline & Kutu grafiği & - & $\begin{array}{c}9 / 10 . \sin 1 f \\
(1 \mathrm{~K})\end{array}$ & - & $\begin{array}{c}6 . \sin 1 f \\
(1 \mathrm{~K}) \\
\end{array}$ & $\begin{array}{c}7 . \operatorname{sinif} \\
(1 \mathrm{~K}) \\
\end{array}$ \\
\hline & $\begin{array}{c}\begin{array}{c}\text { Kök ve yaprak } \\
\text { diyagramı }\end{array} \\
\end{array}$ & - & $\begin{array}{c}\text { 8. sinif } \\
(1 \mathrm{~K})\end{array}$ & $\begin{array}{l}\begin{array}{l}5 . \sin 1 f \\
(1 \mathrm{~K})\end{array} \\
\end{array}$ & - & $\begin{array}{c}\text { 2.ve 4.sinif } \\
(2 \mathrm{~K})\end{array}$ \\
\hline & Serpilme diyagramı & - & $\begin{array}{c}11 / 12 . \sin 1 f \\
(1 \mathrm{~K})\end{array}$ & - & $\begin{array}{l}\text { 8.sinif } \\
(2 \mathrm{~K})\end{array}$ & $\begin{array}{l}\text { 11-12.sinif } \\
(1 \mathrm{~K})\end{array}$ \\
\hline \multirow{3}{*}{$\begin{array}{l}\text { Parametrik ve } \\
\text { parametrik } \\
\text { olmayan testler }\end{array}$} & $\begin{array}{c}\text { t testi (Bağımlı / } \\
\text { Bağımsız) }\end{array}$ & - & $\begin{array}{l}\text { 13. sinif } \\
(1 \mathrm{~K})\end{array}$ & - & - & - \\
\hline & $\begin{array}{c}\text { Ki-kare (Uyum ve } \\
\text { Bağımsızlık) }\end{array}$ & - & $\begin{array}{c}\text { 13. sinif } \\
(2 \mathrm{~K})\end{array}$ & - & - & - \\
\hline & Anlamlılık testi & - & $\begin{array}{l}\text { 11-13. sinif } \\
(2 \mathrm{~K})\end{array}$ & - & - & - \\
\hline \multirow{2}{*}{ Dağılımlar } & Normal dağılım & - & $\begin{array}{l}\text { 11/12. sinıf } \\
(3 \mathrm{~K})\end{array}$ & $\begin{array}{l}9 . \mathrm{sinif} \\
(1 \mathrm{~K})\end{array}$ & $\begin{array}{l}\text { 9/12.sinif } \\
(1 \mathrm{~K})\end{array}$ & $\begin{array}{l}\text { 8. sinıf } \\
(1 \mathrm{~K})\end{array}$ \\
\hline & Örnekleme dağılım & - & $\begin{array}{l}11 / 12 . \sin \mathrm{f} \\
(1 \mathrm{~K})\end{array}$ & - & - & $\begin{array}{l}\text { 9-12.smif } \\
(1 \mathrm{~K})\end{array}$ \\
\hline \multicolumn{2}{|c|}{ Korelasyon ve Regresyon } & - & $\begin{array}{c}\text { 11- 12. sinıf } \\
(7 \mathrm{~K})\end{array}$ & - & $\begin{array}{l}\text { 8. ve } 9 / 12 . \sin 1 f \\
(2 \mathrm{~K})\end{array}$ & $\begin{array}{c}13 . \sin 1 f \\
(2 \mathrm{~K})\end{array}$ \\
\hline \multicolumn{2}{|c|}{ Hipotez testi ve Güven aralı̆̆ } & - & $\begin{array}{l}\text { 11-13. sinif } \\
(4 \mathrm{~K})\end{array}$ & - & $\begin{array}{c}\text { 9/12.sinif } \\
(2 \mathrm{~K})\end{array}$ & $\begin{array}{l}\text { 12-13.sinif } \\
(1 \mathrm{~K})\end{array}$ \\
\hline
\end{tabular}

(K): Kazanımı temsil etmektedir. 
Tablo 10 incelendiğinde, ülkelerde genel olarak merkezi eğilim ve yayılım ölçüleri ile tablo ve grafiğge ait kavramlara yer verildiği görülmektedir. Ancak Türkiye'nin her iki kategoride verilen kavramlar açısından diğer ülkelere kıyasla daha yetersiz seviyede olduğu tespit edilmiştir. Özellikle yayılım ölçüleri olarak varyans, çeyrekler ve yüzdelikler ile tablo ve grafiklerde nokta, kutu grafikleri, kök ve yaprak diyagramı, serpilme diyagramını karşılayacak kazanımlara Türkiye'de yer verilmediği, buna karşın diğer ülkelerin birçoğunda bu kavramları yansıtacak kazanımların olduğu görülmektedir. Örneğin ilkokuldan liseye uzanan süreçte Singapur ve Amerika'da nokta grafiğini; Singapur, Amerika ve Yeni Zelanda'da kutu grafiği ve serpilme diyagramını; Singapur, Amerika, Kore ve Yeni Zelanda'da ise kök ve yaprak diyagramını oluşturma ve yorumlamaya dayalı A, B ve C seviyelerini yansıtacak kazanımlara yer verilmektedir. Ülkelerin en az ikisinde yer verilen bu grafik türlerine Türkiye'de rastlanmamakta ve verilerin görsel olarak sunulmasında daha çok şekil, sütun, çizgi, daire ve histogram grafikleri tercih edilmektedir. Bununla birlikte, ülkemizde diğer ülkelere oranla çetele ve siklık tablolarına veri temsilinde sıklıkla başvurulduğu görülmektedir. Tablo incelendiğinde merkezi eğilim ve yayılım ölçüleri konusunda aritmetik ortalama ve tablo grafikler konusunda ise diğer konu ve kavramlara göre sütun grafiğine daha fazla yer verildiği görülmektedir. Ayrıca bu kavramların yer verildiği sınıf seviyelerinin de daha fazla çeşitlilik gösterdiği görülmektedir. Her ne kadar diğer ülkelerde medyan ve mod kavramları ortaokul seviyesinde verilmeye başlansa da Kore'de bu kavramlar 9. sınıf seviyesinden itibaren verilmektedir. Benzer şekilde diğer ülkelerde histogram kavramı ortaokul seviyesinde verilmeye başlanırken Türkiye'de bu kavrama lise seviyesindeki kazanımlar arasında yer almaktadır. Bununla birlikte parametrik ve parametrik olmayan testler, dağılımlar, korelasyon ve regresyon, hipotez testi ve güven aralığı gibi çıkarımsal istatistiğe yönelik konu ve kavramlara Singapur'da ağırlıklı olarak yer verilirken, Kore'de bu kavramlardan sadece normal dağılımın ele alındığı, Yeni Zelanda ve Amerika'da ise hem kazanım sayısı hem de konu içeriği açısından bu kavramların sınırlı düzeyde tutulduğu görülmüştür. Ülkelerin birçoğunda tek bir konu ya da sınırlı kazanımla da olsa değinilen çıkarımsal istatistik kavramlarına ülkemizde hiç yer verilmemiştir. Diğer bir ifade ile ülkemizde çıkarımsal istatistik konu ve kavramlarının öğrencilere kazandırılması matematik öğretim programının hedef davranışları arasına yerleştirilmemiştir. Ayrıca ülkeler genelinde sınıf seviyesine bağlı olarak matematik öğretim programında yer verilen konular dikkate alındığında daha alt kademelerde genellikle sıklık tablosu, şekil ve sütun grafiği, aritmetik ortalama, mod, medyan gibi kavramalara değinilirken daha üst kademelere doğru standart sapma, çizgi ve daire grafiği, histogram, parametrik ve parametrik olmayan testler, dağılımlar, korelasyon ve regresyon, hipotez testi ve güven aralığ öğretim programlarının basitten karmaşığa doğru ilkesini uygulama noktasında ülkeler ortak adımlar atarken, her bir ülke için sınıf seviyelerine bağlı olarak konunun ele alınma seviyesi değişebilmektedir.

\section{Kaynaklar / References}

Akoğlu, K. (2018). Blending online coursework and small learning communities to examine professional growth in teaching statistics: A phenomenological case study (Unpublished doctoral dissertation). North Carolina State University, North Carolina.

Altıntaş, S., \& Görgen, İ. (2014). Türkiye ile Güney Kore'nin matematik öğretim programlarının karşılaştırmalı olarak incelenmesi, NWSA-Education Sciences, 9(2), 191-216.

Arık, G. (2007). İlkögrretim matematik dersi öğretim programı 3-5. sınıf sayılar öğrenme alanı kazanımlarının NCTM standartları ve Singapur kazanımlarına göre değerlendirilmesi (Yayımlanmamış yüksek lisans tezi). Gazi Üniversitesi, Ankara.

Batur, A., Baydar-Elmas, H., \& Güven, B. (2019, Aralık). Ortaokul matematik ders kitaplarının GAISE Raporu açısından incelenmesi. A. Baki, B. Güven ve M. Güler (Ed.), 4. Uluslararası Türk Bilgisayar ve Matematik Ë̆itimi Sempozyumu Bildiriler Kitabı içinde (ss. 10-18). 4. Uluslararası Türk Bilgisayar ve Matematik Eğitimi Sempozyumu'da sunulan bildiri, http://bilmat.org/turkbilmat2019/dosyalar/files/fulltext-turcomat42019.pdf adresinden erişilmiştir.

Ben-Zvi, D., \& Garfield, J. (2008). Introducing the emerging discipline of statistics education. School Science and Mathematics, 108(8), 355-361.

Burgess, T. A. (2007). Investigating the nature of teacher knowledge needed and used in teaching statistics (Unpublished doctoral dissertation). Massey University, Palmerston North, New Zealand.

Callingham, R., \& Watson, J. M. (2017). The development of statistical literacy at school. Statistics Education Research Journal, 17(1), 181-201.

Chick, H. L., \& Pierce, R. U. (2008). Teaching statistics at the primary school level: Beliefs, affordances, and pedagogical content knowledge. In C. Batanero, G. Burrill, C. Reading \& A. Rossman (Eds.), Proceedings of the ICMI Study 18 and 2008 IASE Round Table Conference, Monterrey, Mexico.

Cooper, L. L. (2002). An assessment of prospective secondary mathematics teachers' preparedness to teach statistics (Unpublished doctoral dissertation). Available from ProQuest Dissertations and Theses database. (UMI No. 3078386). 
Çelik, S., Kul, Ü., \& Çalık Uzun, S. (2018). Ortaokul matematik dersi öğretim programındaki kazanımların yenilenmiş Bloom taksonomisine göre incelenmesi. Abant İzzet Baysal Ĕgitim Fakültesi Dergisi, 18(2), 775795.

Erbilgin, E. (2014). Türkiye'nin ilkokul ve ortaokul matematik öğretim programlarının genel konu izleme haritası ile incelenmesi. Ĕgitim ve Bilim, 39(174), 272-285.

Erdoğan, F., Hamurcu, H., \& Yeşiloğlu, A. (2016). Türkiye, Singapur TIMSS 2011 sonuçlarının matematik programı açısından değerlendirilmesi. Cumhuriyet International Journal of Education, 5(USOS Özel Sayı), 31-43.

Forbes, S. (2014). The coming of age of statistics education in New Zealand, and its influence internationally. Journal of Statistics Education, 22(2). Online: http://www.amstat.org/publications/jse/v22n2/forbes.pdf.

Forster, N. (1995). The analysis of company documentation. C. Cassell \& G. Symon (Eds). Qualitative methods in organizational research: A practical guide. London: Sage Publications.

Franklin, C., Kader, G., Mewborn, D., Moreno, J., Peck, R., Perry, M., \& Scheaffer, R. (2007). Guidelines for Assessment and Instruction in Statistics Education (GAISE) Report: A Pre-K-12 Curriculum Framework. Alexandria, VA: American Statistical Association.

Garfield, J. B., \& delMas, R. (2010). A web site that provides resources for assessing students 'statistical literacy, reasoning and thinking. Teaching Statistics, 32(1), 2-7.

Groth, R. E. (2013). Characterizing key developmental understandings and pedagogically powerful ideas within a statistical knowledge for teaching framework. Mathematical Thinking and Learning, 15(2), 121-145.

Groth, R. E. (2017). Developing Statistical Knowledge for teaching during desing -based research. Statistics Education Research Journal, 16(2), 376-396.

Güven, B., Öztürk, T., \& Özmen, Z. (2015). Ortaokul sekizinci sınıf öğrencilerinin istatistiksel süreçteki deneyimlerinin incelenmesi. Eğitim ve Bilim, 40(177), 343-363.

Güzel, İ., Karataş, İ., \& Çetinkaya, B. (2010). Ortaöğretim matematik öğretim programlarının karşılaştırılması: Türkiye, Almanya ve Kanada. Turkish Journal of Computer and Mathematics Education, 1(3), 309-327.

İncikabı, L., \& Tuna, A. (2012). Türkiye ve Amerika eğitim sistemlerinin 60-72 aylıklar için geliştirilen okul öncesi matematik eğitimi programları açısından karşılaştırılması. Mersin Üniversitesi Eğitim Fakültesi Dergisi, 8(3), 94-101.

Kaytan, E. (2007). Türkiye, Singapur ve Ingiltere matematik öğretim programlarının karşılaştırllması (Yayımlanmamış yüksek lisans tezi). Hacettepe Üniversitesi, Sosyal Bilimler Enstitüsü, Ankara.

Koparan, T. (2012). Proje tabanlı ögrenme yaklaşımının öğrencilerin istatistik okuryazarlı̆̆ seviyelerine ve istatistiğe yönelik tutumlarına etkisi (Yayımlanmamış doktora tezi). Karadeniz Teknik Üniversitesi Eğitim Bilimleri Enstitüsü, Trabzon.

Koparan, T., \& Güven, B. (2013). İlköğretim ikinci kademe öğrencilerinin istatistiksel düşünme düzeylerindeki farklılaşma üzerine bir araştırma. İlköğretim Online, 12(1), 158-178.

Kul, Ü., \& Aksu, Z. (2016). Türkiye, Singapur, Güney Kore ortaokul matematik dersi öğretim programlarının pedagojik alan bilgisi bileşenleri bağlamında karşılaştıılması. Erzincan Üniversitesi Eğitim Fakültesi Dergisi 18(2), 900-921.

Lovett, J. N., \& Lee, H. S. (2018). Preservice secondary mathematics teachers' statistical knowledge: A snapshot of strengths and weaknesses, Journal of Statistics Education, 26(3), 214-222.

Mooney, E. S. (2002). A framework for characterizing middle school students' statistical thinking. Mathematical Thinking and Learning, 4(1), 23-63.

M.E.B. (2005). İlköğretim Matematik Dersi 6-8. Sınıflar Öğretim Programı. T.C. Millî Eğitim Bakanlığı, Talim ve Terbiye Kurulu Başkanlığı. Ankara.

National Council of Teachers of Mathematics (2000). Principles and standards for school mathematics. http://standards.nctm.org. 20 Temmuz 2010.

Neumann, D. L., Hood, M., \& Neumann, M. M. (2013). Using real-life data when teaching statistics: Student perceptions of this strategy in an introductory statistics course. Journal of Statistics Education, 21(1), 59-70. Retrieved June 27, 2015 from http://iase-web.org/Publications.php?p=SERJ.

Newton, J., Dietiker, L., \& Horyath, A. (2011). Statistics education in the United States: Statistical reasoning and the statistical process. In C. Batanero, G. Burrill, and C. Reading (Eds.), Teaching statistics in school mathematics- Challenges for teaching and teacher education (pp. 5-8), 18. ICMI / IASE Çalışması.

Özkan, E. A. (2006). Türkiye, Belçika (Flaman) ve Singapur Matematik öğretim programları üzerine karşılaştırmalı bir çalışma (Yayımlanmamış yüksek lisans tezi). Hacettepe Üniversitesi, Sosyal Bilimler Enstitüsü, Ankara.

Özmen, Z. M. (2015). Farkl lisans programlarında okuyan öğrencilerin istatistik okuryazarliğının incelenmesi (Yayınlanmamış doktora tezi). Karadeniz Teknik Üniversitesi Eğitim Bilimleri Enstitüsü, Trabzon.

Özmen, Z., \& Baki, A. (2017). Farklı programlarda istatistik dersi veren öğretim elemanlarının uygulamalarının istatistik okuryazarlığı bağlamında değerlendirilmesi. Eğitim ve Bilim, 42(191), 323-349. 
Özreçberoğlu, N., \& Kıvanç Çağanağa, Ç. (2016). Güney Kore ile KKTC 'de Uygulanan Matematik Eğitim Sistemlerinin Karşılaştırılması. International Journal of New Trends in Arts, Sports \&Science Education, 5(2), 486-571.

Programme for International Student Assessment [PISA] (2015). https://www.oecd.org/pisa/pisa-2015-resultsin-focus.pdf adresinden alınmıştır.

Reston, E. D. (2005). Assessing statistical literacy in graduate level statistics education. Paper presented at the 55. Session of the International Statistical Institute, Sydney, Australia. Retrieved December 23, 2011 from http://iaseweb. org/documents/papers/isi55/Reston.pdf.

Rumsey, D. J. (2002). Statistical literacy as a goal for introductory statistics courses. Journal of Statistics Education, 10(3), http://www.amstat.org/publications/jse/v10n3/rumsey2.html.

Steen, L. A. (1999). Numeracy: The New Literacy for a Data-Drenched Society. Educational Leadership, 57(2), 8-13.

Tezcan, Ş. (2016). Cebir öğrenme alanı bağlamında Türkiye, Singapur ve ABD (Wisconsin eyaleti) 5-8. Sınıflar matematik ögretim programlarının karşılaştırılması (Yayımlanmamış yüksek lisans tezi). Gaziantep Üniversitesi, Gaziantep.

Topan, B. (2019). Ters-Yüz Sınıf Modeline Göre Tasarlanan Öğrenme Ortamının Ortaokul Öğrencilerinin İstatistik Okuryazarlık Seviyelerine Etkisi (Yayımlanmamış doktora tezi), Trabzon Üniversite Lisansüstü Eğitim Enstitüsü, Trabzon.

Trends in International Mathematics and Science Study [TIMSS] (2015). https://odsgm.meb.gov.tr/meb_iys_dosyalar/2017_06/23161945_timss_2015_on_raporu.pdf_adresinden alınmıştır.

Uğur-Arslan, Z. (2015). Türkiyénin TIMSS Geometri öğrenme alanındaki başarısızlık nedenlerinin karşılaştırılmalı program analizleri ve uzman görüşleri ile belirlenmesi (Yayımlanmamış yüksek lisans tezi). Ankara Üniversitesi, Ankara.

Watson, J. M. (2006). Statistical literacy at school: Growth and goals. New Jersey: Lawrence Erlbaum Associates.

Wild, C. J., \& Pfannkuch, M. (1999). Statistical thinking in empirical enquiry. International Statistical Review, 67(3), 223-265.

Yolcu, A. (2012). An investigation of eighth grade students 'statistical literacy, attitudes towards statistics and their relationship (Unpublished master's thesis). Middle East Technical University, Ankara. 